\title{
Soyun Önemi Bağlamında Yahudi-Haşmoni Krallığı ve Vaftizci Yahya
}

\author{
Tolga Savaş ALTINEL*
}

Öz: Haşmoni Krallığı, M.Ö. 140-M.Ö. 37 yılları arasında Yahudilerin kurmuş olduğu ender bağımsız devletlerden biridir. Ancak bu hanedanlık soyları sebep gösterilerek siyasi ve dini erki kullanmada bir takım sınırlamalara maruz kalmıştır. Onlara geleneksel Yahudi otoriteleri tarafından muhalefet edilmiştir. Bunun asıl sebebi Haşmonilerin Helenleşmeye eğilimli olmalarıdır. Ancak bu muhalefet soylarının üstünlüğüne yönelik iddiaları üzerinde yapılmıştır. Bu çerçevede siyasi ve dini kurum ve unvanlar revize edilmiş, Haşmonilerin Davut soyundan olmadıkları öne sürülerek krallıklarının meşruiyetinin halk tarafından tanınması engellenmiş, iç savaşlarla uğraşmak durumda kalınca da krallıkları tarih sahnesinde ancak yüz yıl kalabilmiştir. Bu yazı soy üstünlüğü argümanının her iki tarafça siyasi bir retorikle ne şekilde kullanıldığını ortaya koymaya çalışacaktır. Bu bağlamda Yahudi dini otoritesini temsil eden Büyük Kurul (Sanhedrin) üzerinde yapılan değişiklikler, Haşmonilerin soyu, Haşmonilerin Kohenliğin gerektirdiği kan saflığını kaybettikleri iddiası ele alınacaktır. Ayrıca Herod ile Vaftizci Yahya’nın soy üstünlüğü konusundaki tavırları karşılaştırılacaktır.

Anahtar Kelimeler: Haşmoni, Seçilmiş Soy, Kohen, Herod, Vaftizci Yahya, Sanhedrin.

The Kingship Experience of Cohens in the Context of Genealogical Superiority: The Kingdom of Hasmoneans

Abstract: Hasmonean Kingdom (140-37 BCE) was one of the few Jewish independent states in history. However, Hasmoneans were not able to exercise their religious and political authority fully because of their genealogy; for the Jewish authorities claimed that their genealogy was not sufficiently pure to do so. The claim of this study is that the real reason for the opposition of the Jewish authorities against the dynasty was due to their Hellenistic tendencies, which surfaced as a rhetorical ploy using genealogy. For this reason, when the Hasmoneans claimed High Priesthood, the opposition created new boundary markers so as to limit their ability of achieving religious authority. On the other end of the spectrum, they denied the Hasmonean claim of kingship because they were not from Davidic lineage. This opposition created an unstable political situation, which eventually led to civil wars. Consequently, the kingdom was able to only survive for a short period of time. In this study the research elaborates on how the two sides utilized the argument of genealogical superiority to construct their respected political arguments. The cases through which the notion of genealogical superiority is discussed includes the administrative revisions on the structure of "Keneset ha-Gedolah", the genealogy of the Hasmoneans, and the claim that the Hasmoneans lost the purity of blood necessary for high priesthood. Furthermore, the diverse stands of Herod the Great and John the Baptist on the issue of genealogical superiority are also discussed.

Keywords: Hasmoneans, Chosen Genealogy, Cohen, Herod the Great, John the Baptist, Sanhedrin.

Marmara Üniversitesi İlahiyat Fakültesi Dinler Tarihi Anabilim Dalı Doktora Öğrencisi.

E-posta: tolgaaltinel@marun.edu.tr 


\section{Giriş}

İsrailoğulları arasında soyun büyük bir gücü ve önemi vardır. Tanrı́nın seçimi soya dayalı olduğu gibi İsrailoğullarının kendi toplumları içindeki misyonlarını da soy belirlemektedir. Mabette kurban ayininde görev alabilmek veya Kutsallar Kutsalı (Kudsü'l-ekdes/kodeş ha-Kodaşîm) bölümüne girebilmek Harun soyundan gelen bir Kohen ${ }^{1}$ olmakla mümkündür. Yine krallığın Tanrı tarafından kutsanması Davut soyundan gelen bir kral olmaktan geçmektedir. ${ }^{2}$

Haşmoni Krallık tarihi, İsrailoğulları arasında soyun önemini dolayısıyla gücünü göstermesi ve soyun sınırlarını belirlemesi açısından önemli örneklerle doludur. Öyle ki rahip olmak için soylarını Harun peygamberin soyuna dayandıran Haşmonilerin zamanla krallaşmaları, onların görev sınırları dışına çıkmaları olarak yorumlanmıştır. Yine Haşmonilerin, siyasi güçlerini etkinleştirmek için geleneğin dışına çıkarak ilk defa zorla Yahudileştirme politikası uygulamaları, Yahudi toplumundaki sosyal sınıflara yeni bir katman katmıştır. Haşmoni Krallı̆̆ı’nı yıkan Büyük Herod’un dahi krallığının meşruiyetini Haşmoni soyu üzerine bina etmeye çalışması soyun bu dönemde kazanmış olduğu önemi göstermektedir.

Haşmoni Hanedanlığının son üyeleriyle çağdaş olan Vaftizci Yahya’nın Kửân ve İncillere konu olan isimlendirilmesi ${ }^{3}$ yine kanaatimizce bu devirdeki soy anlayışına yapılmış bir eleştiri olarak yorumlanabilir. Bu doğrultuda bir soylu olmasına rağmen Yahyảnın ismiyle ve söylemiyle soyun ayrıcalığına meydan okuyan bir kişi olup olmadığı sorusu elinizdeki çalışmada ele alınacaktır.

Makalemizde Yahudi kültüründeki soy anlayışının bir krallığı nasıl şekillendirdiği ve bu dönemdeki yöneticilerin bu güç karşısında ve onu elde etmek için neler yaptıkları örneklerle gösterilmeye çalışılacaktır. İlk önce Haşmoni Krallığı’nın kısa bir tarihi sunulacak, daha sonra sırasıyla soyun gücünü ve önemini gösteren konular ele alınacaktır. Bunun bir örneği olarak da ne siyasi ne de dini erki tam olarak elde edememeleri ve dönemin soy üstünlügü mücadelelerinde iki farklı tavır sergileyen Büyük Herod ile Vaftizci Yahya karşılaştırmasına yer verilecektir.

Haşmoni Krallığı tarihinin yazımındaki birincil kaynaklar, ilk iki kitabı Deuterokanonik ${ }^{4}$ olan Makkabiler kitapları ${ }^{5}$ ile Yahudi Tarihçi Josephus'un kitaplarıdır. ${ }^{6}$ Bu kaynakları analiz eden modern araştırmacıların düşüncelerine de yer verilecektir.

1 Musa peygamberin kardeşi Harun'un soyundan gelen rahipler için kullanılan bir terimdir. II. Mabedin yıkılmasıyla önemlerini kaybetmişlerdir. Günümüz Yahudiliğinde sembolik görevleri vardır.

2 "Soyun ve krallı̆̆ın sonsuza dek önümde duracak; tahtın sonsuza dek sürecektir" (I. Samuel 7:16) Öyle ki sürgünde olan Yahudi toplulukları Davut soyundan geldiklerine inanılan Re’sul Câlut (Arm. Reş Galuta) tarafından idare edilmişlerdir (bk. Arslantaş, "Re’sülcâlût", DİA, XXXV, 5-6).

3 Meryem 19/7; Markos 6:17-29; Matta 14:3-11.

4 Roma Katolik Kilisesi, 1546 yılında Trent Konsülü’nde Kutsal Kitap listesine sonradan bazı kitaplar eklemiştir. Söz konusu kitaplardan "Deuterokanonik" diye söz edilmektedir. Protestanlar ise bu kitapları "Apokrifler" diye adlandırırlar. Bu kitaplar Tobit, Yudit, Ester (Eski Antlaşma’daki özgün metne bazı ekler içeren Grekçe çevirisi), Bilgelik, Sirak, Baruk, Yeremyảnın Mektubu, Azaryảnın Duası ve Üç Genç Adamın Ezgisi, Suzanna, Bel ve Ejderha, 1. Makkabiler, 2. Makkabiler, 3. Makkabiler, 1. Esdras, 4. Ezra, Manaşşe’nin Duası, 151, Mezmur ve 4. Makkabiler'dir.

5 I. Makkabiler kitabı Antiyokus Epifanes'ten (M.Ö. 175) Yuhanna Hirkanus’a (M.Ö. 134) kadar olan dönemi anlatmaktadır. II. Makkabiler, Başkohen III. Oniyas'ın (yaklaşık M.Ö. 180) zamanından Nikanor’un (M.Ö. 161) ölümüne dek Yahudi tarihindeki olayları anlatmaktadır. III. Makkabiler M.Ö. 217 yılında IV. Ptolemi’nin Mabedin Kutsallar Kutsalı olan bölümüne girmesini ve Yahudilere yaptığı baskıları anlatır. IV. Makkabiler iki bölümden oluşmaktadır. İlk bölüm (4: 1-26) IV. Antiyokus'un baskısını; ikinci bölüm (5: 1-7:23) ise Kohen Elezar’ın katledilmesini anlatmaktadır.

6 Tarihçi Josephus'un, The Antiquities of the Jews adlı eseri yirmi kitaptan oluşan ve Âdem'den başlayan bir Yahudi Tarihidir. Diğer kitabı Jewish War ise Selevkos kralı IV. Antiyokus'tan Romalı İmparator Titus’a kadar sürede geçen 


\section{Haşmoni Krallı̆̆ı'nın Kısa Tarihi}

Haşmoni Krallığı, M.Ö. 140-M.Ö. 37 yılları arasında Kudüs başkent olmak üzere Filistin topraklarında Harun peygamberin soyundan gelen, Mabed'in ayrıcalıklı rahipleri Kohenlerin kurmuş olduğu Yahudi devletidir. M.Ö. 200'te "Büyül" lakaplı III. Antiyokus'un, Filistin’i ele geçirmesiyle Yehuda'da Selevkosların hâkimiyeti başlamıştır. ${ }^{7}$ IV. Antiyokus'un Misır seferinde Kudüs'e girerek Mabed'i kirletmesi ve buraya Zeus heykeli dikmesi, siyasî ve malî olarak zor durumda olan Yahudilerin milli-dini duygularının yeniden uyanmasına sebep olmuştur. IV. Antiyokus, Mabed'de kurban kesmeyi, Şabat'ı ve sünneti de yasaklayınca ${ }^{8}$ geleneksel Yahudiler ve Helenleşmiş Yahudiler arasında süregelen çekişmeye müdahil olmuştur. ${ }^{9}$

Modin'de Kohen Matatiyas, IV. Antiyokus'un izlemiş olduğu Helenleştirme siyasetine karşı durarak bir ayaklanma başlatır. ${ }^{10}$ Kralın buyruğu gereği sunakta yabancı ilahlara kurban kesmeyi reddeden Matatiyas, kurban kesmeye teşebbüs eden Helenist bir Yahudiyi ve kralın adamlarını da öldürünce isyan başlamış olur. Beş oğlu (Elezar Avaran, Yehuda Makkabi, Simon Tasi, Yohannan Gaddi, ve Yonatan Apfus) tarafından devam ettirilen bu direniş "Makkabiler İsyanı” adını alacaktır. ${ }^{11}$ Başkaldırıyı Matatiyas başlatmasına rağmen onun ölümünden sonra oğlu Yehuda Makkabi’nin M.Ö. 165’te II. Mabed’i arındırma başarısı, isyanın onun lakabı ile anılmasını sağlamıştır. Yehuda Makkabi’nin ölümü üzerine kardeşleri ${ }^{12}$

Yahudi tarihindeki olayları anlatan yedi kitaplık bir koleksiyondur. Üçüncüsü olan Against Apion ise yedi kitaptan oluşan ve Yahudiliği savunan bir reddiye kitap koleksiyonudur.

8 IV. Antiyokus'un niçin böyle bir tutum sergilediği tarihçiler arasında tartışma konusudur. Helenistik dünya dinlere özgürlük tanırken IV. Antiyokus'un Yehuda bölgesinde Yahudilerin dinlerini yaşamasını engellemeye çalışması tuhaf karşılanmaktadır. Bickerman, Helenleşmiş Yahudilerin bu dini kısıtlamaların arkasında olduğunu söylemektedir. Bir anlamda Bickerman, IV. Antiyokus’un baskıcı tutumunu Helenleşmiş Yahudilere yüklemektedir. Bickerman'ın görüşlerine katılmakla beraber Tcherikover'e göre 'Kudüs'teki Antakya' tabiriyle ifade ettiği siyasi şekillenme Kudüs'teki hizipleşmenin ana nedenidir. Ona göre hizipleşmenin nedeni dini ve etnik bir ayrımdan ziyade Kudüs'teki Hellenistik yapıdaki kültürel şehirleşmedir (polisleşme) (ayrıca bk. Tcherikover, Hellenistic Civilization and the Jews, s. 211). Rappaport bu dönemde Yahudi seçkinlerinin birçok gruba ayrıldığını söyler. Ona göre Oniaslar ve Tobiadlar, Helenleşmiş Yahudiler ve Haşmoniler, Selevkos taraftarları ve Ptolemi taraftarları şeklinde hizipleşmeler vardır. Helenistik Yahudiler bu dinî zulmün baş aktörleridir. Menelaus taraftarları bunu başlatmış, Mısır'daki yenilginin etkisinden kurtulamamış olan IV. Antiyokus da bütün bunlara katkı vermiştir (“Maccabean Revolt", s. 437-438).

9 Bu dönemde iki tür Yahudiliğin varlığından bahsetmek mümkündür. Bunlardan ilki mabet kültü etrafında şekillenen ve Aramice konuşan Filistin Yahudiliği diğeri ise Helenistik geleneğin etkisinde, Grekçe konuşan Misır, Antakya ve Ege havzasında yaşayan Diaspora Yahudiliğidir. Helenistik Yahudilik, İkinci Mabed döneminde Kudüs'te de mevcuttu. Burada, geleneksel Yahudilik taraftarları ile Helenistik Yahudilik taraftarları, çatışma halindeydiler. Helenleşmiş Yahudiler günlük hayatta bir Yunanlı gibi yaşamaya başlamış, gymnasiumda spor müsabakalarına katılırken Yahudiliğinin alameti olan sünnetin izlerini silebilmenin yollarını düşünmüştür.

10 Tcherikover ayaklanmanın bu olaydan bir yıl önce Hasidiyanlar (Tutucu Yahudiler) tarafından başlatıldığını söylemektedir. Modin'deki bu hikâyeye ise şüpheyle yaklaşmaktadır. Ona göre, Makkabi harekâtı Hasidiyanlar ayaklanmasının devamıdır (Hellenistic Civilization and the Jews, s. 204-206). Hasidiyanlar, Selevkos Kralı IV. Antiyokus zamanında Makkabi isyanına katılan Helenleşmeye karşı olan bir topluluktur (Mansoor, "Hassideans", Encyclopedia Judaica, VIII, 455).

11 I. Makkabiler 2: 1-5.

12 Yehuda Makkabi’nin kardeşlerinden Avaran Elezar, V. Antiyokus’un Lisias ile Yehuda bölgesine düzenlemiş olduğu bir seferde, kralı öldürmek için yaptığı bir saldırıda ordudaki fillerden birinin altında kalarak ölmüştür. 
arasından Yonathan daha sonrada ${ }^{13}$ Simon, Makkabilerin lideri olmuşlardır. Yehuda Makkabi’nin ağabeyi Simon'un II. Dimitros zamanında Etnark (Ulusun Önderi) ${ }^{14}$ olarak ilan edilmesi Haşmoni hanedanlığı ${ }^{15}$ için bağımsızlığa giden dönüm noktalarından biri olmuştur.

Makkabilerin üçüncü neslinden, Simon oğlu Yuhanna Hirkanus bölgedeki fetihleriyle etnarklığın sınırlarını Galile’nin kuzeyinden Masada’ya; Akdeniz’den Ürdün’e kadar genişletmiştir. ${ }^{16}$ Samiriye bölgesini ele geçirmesi onun halk desteğini kazanmasını sağlamıştır. Şekem'i harabeye çevirmesi ve Gerizim dağındaki mabedi yıkması ${ }^{17}$ Yahudiler için büyük bir zafer olarak algılanmıştır. Diğer taraftan Yuhanna Hirkanus, Yahudi tarihinde ilk defa rastlanacak bir uygulamayı hayata geçirerek Edomluları ${ }^{18}$ zorla Yahudileştirmeye başlamıştır. ${ }^{19}$ Askeri alandaki başarılarının etnarklığı tam bir bağımsızlığa dönüştürmeye başladığı sırada içeride bir takım yönetim sıkıntıları ortaya çıkmıştır. Josephus, Helenleşen Haşmoni krallığında ortaya çıkan iç sorunları Ferîsî ${ }^{20}$ ve Sadûkî ${ }^{21}$ çekişmesi olarak görür. ${ }^{22}$ Ömrünün son yıllarını iç sorunlarla geçiren Yuhanna Hirkanus'un vasiyetinde eşinin kraliçe; oğlu Aristobulus'un da Başkohen olmasını istemesine rağmen Aristobulus (M.Ö. 104-103) vasiyete karşı gelerek babasının ölümüyle annesi ${ }^{23}$ ve kardeşlerini hapse atmış ve babası gibi iki liderliği (Başkohenlik-Siyasi Liderlik) de üstlenerek kendini kral ilan etmiştir. Ancak krallığ1 bir yıl sürmüştür. Bir yıl sonra ölmesiyle hapisteki kardeşi Alexander Yanay (M.Ö. 103-76) tahta çıkmıştır. ${ }^{24}$ Alexander içeride Ferîsîlerin muhalefetiyle karşılaşmış ve her firsatta bu

13 John Gaddi, Yonathan zamanındaki bir seferde öldürülmüştür (I. Makkabiler 9: 35-38).

14 Halk anlamına gelen ethnos ( $(๕ \theta v o \varsigma)$ ile yönetici, anlamına gelen archon (ä $\rho \chi \omega v)$ Yunanca kelimelerin birleşmesiyle meydan gelen siyasi unvandir.

15 Makkabiler, Simon Tasi zamanında hanedanlık hüviyeti kazanmış ve kurmuş oldukları krallık Haşmoni Krallığı olarak anılmıștır.

16 Bickerman, From Ezra to the Last to the Maccabees, s. 151.

17 Josephus, The Wars of the Jews, 1. 63-66; Josephus, The Antiquities of the Jews, 13. 255-257, 275-281. Tcherikover, Hellenistic Civilization and the Jews, s. 245-246.

18 Tanah'a göre Yakup peygamberin kardeşi Esav'in soyundan geldiğine inanılan topluluk.

19 Bickerman, From Ezra to the Last to the Maccabees, s. 150; Dabrowa, The Hasmoneans and Their State, s. 77.

20 Ferîsî, ayrılanlar anlamında İbrani "ceperushim" kelimesinden türetilmiştir. Ancak ayrılmanın bir övgü mü yoksa yergi mi ifade ettiği tartışılmaktadır. Baumgarten, II. Mabet döneminde Ferîsîlerin bunu olumlu anlamda kullandığını daha sonra kanun konusunda 'uzman' anlamının bu kelimeye yüklendiğini düşünmektedir (bk. Baumgarten, “The Name of the Pharisees”, s. 411-428). Ferîsîler dini gevşeklik gösteren sıradan halktan kendilerini ayırdıkları için ayrilıkçılar manasında veya Tevrat'ı yorumlamalarından dolayı 'yorumcular' anlamında isimlendirilen cemaattir. Tevrat öğretisini öne çıkaran ve ağırlıklı olarak Tevrat âlimlerinden oluşan bir gruptur (Gürkan, Yahudilik, s. 37).

21 Sadûkîler, aristokrat bir Yahudi grubudur. Sadûkîler hakkında bilgi kaynakları üç ana başlık altında toplanabilir: 1) Tarihçi Josephus'un Kitapları 2) Yeni Ahit'in bütün külliyat1 3) Rabbani Literatür. Ancak bu kaynaklardaki bilgiler Sadûkîlerin doğrudan görüşlerini değil de muhalifleri tarafından ele alınışlarını ihtiva etmektedir. Abraham Geiger'in Sadûkîlerin I. Mabedin ilk Koheni Sadok soyundan geldikleri iddiası hala popülerliğini korumakla beraber araştırmacılar tarafından tartışılmaktadır. Jonathan Klawans Sadok ve Sadûkîler arasında soydan ziyade akılcılık konusunda bir ilişki kurmuş gözükmektedir (“Sadducees, Zadokites and the Wisdom of Ben Sira”, s. 261-276).

22 Josephus, The Antiquities of the Jews, 13. 288-296.

23 İsmini bilmediğimiz bu kraliçe hapishanede açlıktan ölmüştür (Josephus, The Wars of the Jews, 1. 71; a. mlf., The Antiquities of the Jews, 13.302).

24 Josephus, The Antiquities of the Jews, 13. $301 \mathrm{vd}$; a. mlf., The Wars of the Jews, 1. 70. 
muhalefeti şiddetle bastırmıştır. Son yıllarını Yahudi gruplarının mücadeleleri arasında kalarak geçiren Alexander Yanay, Ragaba Kalesi kuşatmasında ölmüş ve sefer sırasında yanında olan eşi Salome Alexandra tahta çıkmıştır. ${ }^{25}$ Salome Alexandra, I. Alexander'ın ölümünden sonra dokuz yıllık bir süre içerisinde Yahudi tarihinin ikinci kraliçesi ${ }^{26}$ olarak hüküm sürmüştür. Salome’nin kraliçe olmasıyla Sadûkîler lehine olan politik hava değişmeye başlamış ve Ferîsîler Sanhedrin'de güçlenmişlerdir.

Salome’nin ölümüyle iki oğlu ${ }^{27}$ arasında taht kavgası başlamıştır. II. Hirkanus, annesi gibi Ferîsîlerin müttefiki olmuştur. Kardeşi II. Aristobulus ise babası gibi Sadûkîleri desteklemiştir. Ferîsîlerin desteklediği II. Hirkanus yaklaşık üç ay elinde tutmuş olduğu krallığı, bir isyan başlatan kardeşi II. Aristobulus'a (M.Ö. 67-63) bırakmak zorunda kalmıştır. ${ }^{28}$ Kudüs'e sı̆̆ınan II. Hirkanus daha sonra bir antlaşma ile kardeşine teslim olmuş Mabed’in gelirlerinden faydalanmak şartıyla krallığ 1 ve Başkohenliği kardeşine bırakmıştır. ${ }^{29}$

II. Hirkanus, Edomlu Antipater'un ikna etmesiyle önce Nebati Kralı Arates’e iltica etmiş onun desteğini aldıktan sonra yeniden kardeşiyle taht kavgasına girmiştir. ${ }^{30}$ Kudüs'ü kuşatan Nabatîler bölgeye Romalıların gelmesiyle çekilmek zorunda kalmıştır. Romalı General Pompey de kendi çıkarları açısından II. Hirkanus'un Başkohenliğini uygun gördüğü için II. Aristobulus'u esir alarak sürgüne göndermiştir. ${ }^{31}$ Pompey, Hirkanus'u Yahudilerin başına tenzili rütbe olmak üzere etnark olarak atamıştır. II. Hirkanus, Romalıların lütfuyla tahta geçen ve konumunu korumak için onların yardımına ve desteğine muhtaç bir yönetici olmuştur.

Büyük Herod'un babası Edomlu Antipater, II. Hirkanus'a muhalif Yahudi grupları etkisiz hale getirmiş ve kısa süre sonra da II. Hirkanus'u devre dışı bırakıp Yehuda bölgesinin ${ }^{32}$ denetimini ele geçirmiştir. Antipater, Julius Caesar’ın Mısır'daki düşmanlarını yenmesine

25 Zeitlin, “Queen Salome and King Jannaeus Alexander”, s. 22.

26 İlk Kraliçe Atalya (M.Ö. 841-835).

27 C. Saulnier II. Hirkanus ve II. Aristobulus'un soyları hakkında ilginç bir iddiada bulunur. Buna göre II. Hirknaus I. Aristobulus'un oğlu; II. Aristobulus ise Alexander Yanay'ın oğludur (Dabrowa, The Hasmoneans and Their State, s. 120).

28 Josephus, The Wars of the Jews, 1. 123; a. mlf., The Antiquities of the Jews, 14. 11-14; Dabrowa, The Hasmoneans and Their State, s. 97.

29 Josephus, The Antiquities of the Jews, 14:4.

30 Josephus, The Wars of the Jews, 1. 123; Josephus, The Antiquities of the Jews, 14:8-25; Dabrowa, The Hasmoneans and Their State, s. 97-98.

31 Bickerman, From Ezra to the Last to the Maccabees, s. 171; Josephus, The Antiquities of the Jews, 14:48-77. II. Aristobulus sürgüne götürüldügü Roma’dan oğlu Alexander ile dönerken zehirlenerek ölmüş; oğlu da Romalı Scipo tarafından idam edilmiştir (Josephus, The Antiquities of the Jews, 14:140; Josephus, The Wars of the Jews, 1:84-85).

32 Yehuda bölgesi ismini Yakup’un dördüncü oğlu Yehuda soyundan gelenlerin Kenan topraklarında yerleştiği güneydeki geniş bölgeden almıştır. Birleşik krallık dağıldıktan sonra güneydeki krallığı ve son olarak Babil sürgününden dönenlerin yerleştiği bölgeyi ifade etmek için kullanılmaktadır. Herod ve Roma hâkimiyetindeki Yahuda eyaleti (Yahudiye) ise daha geniş coğrafi bölgeleri ifade için kullanılmıştır. Herod Krallığı’nda Yahudiye Samiriye ve Edom’u da içine bir alan iken Roma Eyaleti olan Yahudiye, Galile, ve Samiriye’yi de içine alan idari bir bölge olmuştur. 
yardımcı olunca ${ }^{33}$ Romalılar onu doğrudan kendilerine bağlı bir idari konuma (procurator: vekil) yükseltmişlerdir. ${ }^{34}$ Antipater de oğlu Phasael'i Kudüs'e ve diğer oğlu Herod'u Celile’ye yönetici olarak atamıştır. ${ }^{35}$

M.Ö. 43’te Antipater’in düşmanları tarafından zehirlenerek ${ }^{36}$ öldürülmesinin ardından oğlu Herod, Yehuda bölgesindeki en güçlü adam olmuştur. Fakat Kudüs'teki aristokratlar onun haksız yere bu konuma geldiğini düşündüklerinden Romalıların onu görevden almasını sağlamaya çalışmışlardır. M.Ö. 40 yılında II Aristobulus'un oğlu, Antigonus, Partlar’’ yanına çekerek kendini kral ilan etmiştir. ${ }^{37}$ Pompey'in II. Hirkanus'u tahta geçirmesinden yirmi yıl sonra muhalif olarak Antigonus amcasına başkaldırmıştır. Bu ayaklanmada Herod Roma’ya kaçmıştır. Hirkanus, Babil’e götürülmüş ve dört yıl boyunca Babil Yahudileri arasında saygı görerek yaşamıştır. ${ }^{38}$

Romalılar Partlılar’n Yehuda bölgesinden uzaklaştırılmasını ve bölgeyi kendi seçtikleri bir yöneticiyle yeniden kontrol altına almak istedikleri için yeniden Herod'u görevlendirmiş ve Roma Senatosu onu Yahudilerin Kralı yapmıştıryapmıştır (M.Ö. 37) ${ }^{39}$. Herod, Roma lejyonuyla Kudüs'e geri dönünce, muhaliflerinden acımasızca intikam almış ve Antigonus’u Markus Antonius’a teslim etmiştir. ${ }^{40}$ Herod, Haşmoni Hanedanını kontrol altına almış, yönetiminden rahatsızlık duyan Yahudi aristokratlarını ortadan kaldırmıştır. ${ }^{41}$ Böylece Haşmoni Krallığı yıkılmış ve Kohenlerin krallık deneyimleri son bulmuştur.

\section{Haşmonilerin Başkohenlik ve Krallık İle İlgili Meşruiyet Sorunları}

\subsection{Haşmoni İsmi ve Soylarının Kökeni Meselesi}

Tanah’in nüfus kütüklerini andırır bir görüntü içinde olmasının sebeplerinden biri, soyun görev sınırlarını belirleyici bir ölçüt olmasıdır. Bu anlayış İncillere de yansımıştır; bu sebeple İsảnın Davut soyundan geldiğini ispatlamak için iki uzun şecereye yer verilmiştir. Mesih olabilmek Dâvûdî bir soydan gelmeye bağlıdır. İsa’nın bağlıları bu durumu dikkate almış görünmektedir. Haşmoniler için de benzer bir durum geçerli olduğu için onlar da, görev meşruiyetini sağlayacak bir soy bilgisine ihtiyaç duymuşlardır. Ancak Haşmonilerin

33 Josephus, The Antiquities of the Jews, 14:127-137.

34 Josephus, The Antiquities of the Jews, 14:143.

35 Josephus, The Antiquities of the Jews, 14:158.

36 Josephus, The Wars of the Jews, 1. 225.

37 Josephus, The Wars of the Jews, 1. 248.

38 M.Ö. 36'da Romalıların yardımıyla Antigonus'u yenen Herod, Hirkanus'un Partlardan yardım alıp tekrar tahta geçmek istemesinden korktuğu için onu Kudüs’teki başrahiplik görevine geri çağırdı. Teklifi kabul eden Hirkanus Herod tarafından saygıyla karşılanıp sofrasında baş makam verildi ve eyalet konseyinin başkanlığına atandı. Fakat M.Ö. 30'da Hirkanus, Nebatilerle birlik olup Herod'a tuzak kuracağı gerekçesiyle öldürüldü.

39 Josephus, The Wars of the Jews, 1. 282.

40 Josephus, The Antiquities of the Jews, 15. 5.

41 Hanedanlığın şeması için bkz. Tablo 1. 
Başkohenlik makamına çıkışları uzun bir aradan sonra ve harici etkilerle gerçekleşince, soyları hakkındaki bilgiler (Hârûnî-Sadûkî) sorgulamayı gerektirmiştir. Makkabiler Kitabı'nda Haşmonilerin Kohen soyundan geldikleri şöyle belirtilmektedir:

O günlerde, Yoarib soyundan bir kâhin olan Şimon oğlu, Yuhanna oğlu Matatiyas Yeruşalim'den ayrılıp Modin'e yerleşti. ${ }^{42}$

Diğer bir kaynak olan Josephus'un kitabında paralel bir soy bilgisi yer almaktadır. Bu bilgi aynı zamanda Haşmoni isminin kaynağını da göstermektedir:

O günlerde Matatiyas adında bir adam vardı. Modin'de ikamet ediyordu. O, Haşmona (Asamoneus) oğlu Simon oğlu John’un oğludur. Yoarib soyundan bir Kohendir. Ve Kudüs'in yerlisidir. ${ }^{43}$

Modin'de yaşayan bir Kohen olan Haşmoni oğlu Matatiyas beş oğlu ile silahlan$\mathrm{d}_{1} . .{ }^{44}$

Bu iki kaynağın birleştikleri noktalardan birisi hiç şüphesiz Haşmoniler’in soylarının Davut zamanındaki bir Kohen aile liderine dayanmış olmasıdır. ${ }^{45}$ Bunun vurgulanmasının sebebi muhtemelen Haşmonilere Başkohenlik unvanı verilmesinin önünü açmaktır. Ancak kaynak itibarıyla bu soy kütüklerinin tarafsız oldukları söylenemez. Öncelikle Makkabiler kitabı Haşmoni propagandası yapan bir kitap olması hasebiyle bu tür bir soy bilgisine yer vermiş olabilir. Tarihçi Josephus'un kendi soyunu Haşmonilere dayandırması da onun rivayetinin güvenirliliğini azaltmaktadır. Ayrıca Yoarib soyundan gelen bir Kohen ailesinin süregelen Başkohenlik silsilesiyle bağlantısı bulunmamaktadır. ${ }^{46}$ Davut zamanındaki bir Kohen aile liderinin Haşmoniler ailesine kadar uzanan soy zinciri elimizde mevcut değildir. Böyle olunca Haşmonilerin, meşruiyetlerini sağlamak için Yoraib’e dayalı bir soy bilgisi icat etmiş olabileceklerini düşünüyoruz. ${ }^{47}$

Ancak Schofield-VanderKam "Were the Hasmoneans Zadokites" adlı makalelerinde eldeki kaynaklara ihtiyatla yaklaşmakla beraber Haşmonilerin Sadok soyundan geldiği

42 I. Makkabiler 2:1

43 Josephus, The Antiquities of the Jews, 12. 265.

44 Josephus, The Wars of the Jews, 1. 7.

45 Birinci kura Yehoyariv’e (Yoarib) düştü, ikincisi Yedaya’ya, dördüncüsü Seorim’e, beşincisi Malkiya’ya, altıncısı Miyamin'e, yedincisi Hakkos’a sekizincisi Aviya'ya, dokuzuncusu Yeşu’ya, onuncusu Şekanya'ya, on birincisi Elyaşiv’e on ikincisi Yakim'e, on üçüncüsü Huppa’ya, on dördüncüsü Yeşevav’a, on beşincisi Bilga'ya on altıncısı İmmer'e, on yedincisi Hezir'e, on sekizincisi Happises'e, on dokuzuncusu Petahya’ya, yirmincisi Yehezkel'e yirmi birincisi Yakin'e, yirmi ikincisi Gamul'a, yirmi üçüncüsü Delaya’ya, yirmi dördüncüsü Maazya’ya düştü (I. Tarihler 24:7-18).

46 Yoarib'in Sadok soyundan gelen bir Başkohen olduğu I. Tarihler 6:4-15 listesinde yer almaz. I. Tarihler 24. Bab’da onun sadece kohen aile başı olduğu aktarılır. Bu durumun tek istisnası Yoraib’i bir Başkohen olarak gören Seder Olam Zuta isimli Yahudi kronolojisidir (Bavli, Dünyanın Kısa Tarihi, s. 37-40).

47 Nehemya kitabında antlaşmayı onaylayan aileler arasında Yoarib ismine ve soyuna rastlanmazken I. Tarihler 24. Bab’da Kohen isimlerine Yoarib ile başlanması oldukça dikkat çekicidir. 
sonucuna ulaşmışlardır. Makale Haşmoniler ile Yoarib arasındaki soy zincirine dokunmaksızın ilk önce Yoarib’in Elezar soyundan geldiğini ispatlamaya çalışmaktadır. ${ }^{48}$ Daha sonra bir adım daha atarak sürgün sonrası Kohen ailelerinden Yedaya ile dönemin Başkoheni Yeşu arasında bir ilişki kurarak Yeşu'nun Yedaya ailesinden olduğu sonucuna ulaşmaktadır. ${ }^{49}$ Makalenin ikinci kısmı ise, Essenîlerin ${ }^{50}$ ve Ferîsîlerin itirazlarının Haşmonilerin soylarıyla ilişkili olmadığını açıklamak üzerine kuruludur. Buna göre Essenîler hakkında bilgi veren Kumran Yazmaları’nda Haşmoni Başkoheni için “Zalim Kohen” veya Alexander Yanay için “Kızgın Aslan” lakaplarının kullanılması, onların zulmüne karşı söylenmiş olmaktadır. Yine yazarlara göre Hirkanus veya Alexander Yanay’ın ${ }^{51}$ annelerinden ötürü Başkohenliği kaybettiğine dair Ferîsîlerin iddiası ${ }^{52}$ Haşmonilerin soyunun kökeninden ziyade kralın Başkohenlik için gerekli kan saflığını daha sonradan kaybettiği şeklinde anlaşılmalıdır. ${ }^{53}$ Makalede Ferîsîler ve Essenîler'den Haşmonilere gelen itirazların soyla ilgili olmadığı çıkarımı hiç şüphesiz Haşmonilerin, Sadok ve Elezar'ın soyundan geldiği çıkarımından daha başarılıdır. Yedaya ve Yoarib isimlerinin yan yana zikredilmesinden bu ikisi arasında bir bağ olduğu sonucuna ulaşmak sağlam bir zeminden yoksundur. Bu yüzden de tartışmaya açıktır.

Kanaatimizce Haşmonilerin Yoarib soyundan veya ötesinde Sadûkîler soyundan gelen Kohenler olduğu iddiasını şüpheye düşüren durum, Makkabilerin Başkohen olmadan önce bu makamı vekâleten idare ediyor gibi görünmeleridir. Yehuda Makkabi, siyasi olarak güçlü olduğu bir devirde Alkimus’a Başkohenliği bırakmaktadır. Yehuda Makkabi M.Ö. 165-162 yılları arasında yapmış olduğu düşünülen Başkohenlik görevini, Selevkos desteğinde Kudüs’e gelen Alkimus’a bırakmıştır. ${ }^{54}$ Hasidiyanların Alkimus'u Başkohen olarak kabul etmeleri ${ }^{55}$

48 Buna göre I. Tarihler 24. Bab'da yirmi dört Kohen aile liderinin ismi vardır. İlk sırada Yoarib bulunmaktadır. Kohen ailelerini Elezar ve İtamar soyuna ayırırken- ister iki Elezar bir İtamar şeklinde ister tek tek ayıralım - Yoarib ilk sırada yer aldığı için Elezar soyundan olacaktır.

49 Öyle ki Ezra kitabında yabancı evlilik yapan aileler sayılırken Yeşu, Yedaya ailesini temsil eder gibi İmmeroğulları, Harimoğulları ve Paşhuroğulları yanında zikredilmiştir. Daha sonra da Nehemya 11:3-19 ve I. Tarihler 9:2. 17'deki soy kütüklerini kıyaslayarak ve Nehemya 12:1-7 ve 12-21'de Kohenlerin isimleri sayılırken Yedaya ve Yoarib'in ardıl olmasından yola çıkarak ikisi arasında bir ilişki olabileceğini belirtmiştir.

50 Münzevi ve apolitik bir grup olarak küçük bir kısmı Mabet yakınlarında konumlanan gezgin vaizlerdir. Büyük bir kısmı ise Kumran cemaatiyle özdeşleştirilen II. Mabet ve dini otoritenin meşruiyetini reddederek Ölü Deniz civarında toplumdan ayrı komün bir hayat yaşamışlardır (Gürkan, Yahudilik, s. 37).

51 Josephus, The Antiquities of the Jews, 13. 290-292. Talmud (Kiddushin, 66a) ve Josephus'un kitabında ele alınan bu hikaye genel olarak aynı gibi gözükse de bir takım farklılıklar vardır. Olayın hangi Haşmoni lideri yaşandığı ve Elezar'in kim olduğu farklılık arz etmektedir (Tcherikover, Hellenistic Civilization and the Jew, s. 255).

52 Hikâyeye göre Elezar isminde bir kişi Yuhanna Hirkanus’a Başkohenlikten el çekmesi gerektiğini söylemiştir. Annesinin IV. Antiyokus zamanında esir düştüğü için, Başkohenin sahip olması gereken saflığı kaybettiğini sonuçta Başkohen olamayacağını bildirmesiyle ortam bir anda gerilmiştir.

53 Schofield-VanderKam, "Were the Hasmoneans Zadokites?", s. 73-87.

54 I. Makkabiler 2:42, Bickerman, From Ezra to the Last to the Maccabees, s. 128. Tcherikover, Hellenistic Civilization and the Jews, s. 229.

55 Hasidiyanlar, Helenleşme karşıtı tutucu Yahudilerdir (bk. Kutluay, İslâm ve Yahudi Mezhepleri, s. 189). Kanaatimizce Yehuda’nın Alkimus'un Başkohenliğine itiraz etmemesi, babası Matatiyas zamanında Makkabi harekâtını destekleyen Hasidiyanlarla yapılan ittifakı bozmamak amacıyladır. 
ve Haşmonilere de bunu benimsetmeleri, Alkimus'un bir Oniasl1 ${ }^{56}$ olduğu bilgisini kuvvetlendirmektedir. ${ }^{57}$ Aksi takdirde Alkimus'un sade bir Kohen olarak Yoarib soyundan gelen Haşmonileri indirerek Başkohenlik makamına oturması bu kadar kolay olmamalıdır.

Yine Yehuda Makkabi'nin öldürülmesiyle yerine geçen kardeşi Yonathan Başkohen olabilmek için altı yıl beklemek zorunda kalmıştır. Bu dönem Başkohenlik makamının fetret devri ${ }^{58}$ olarak anılmaktır. Bu dönemde kimin Başkohenlik yaptığı bilinmemektedir. M.Ö. 152 yılında Yonathan’n bu makama gelmesi siyasi başarısıyla eş zamanlıdır. Makkabilerin Başkohenliğinin Yahudi toplumu tarafından kabulü ancak kardeşi Simon’un liderliğinde şartlı olarak gerçekleşmektedir. Öyle ki Simon’un Başkohenliğe seçilmesi ilk defa bir konsey tarafından belirlenmiş ve Simon ' bir peygamber gelinceye kadar' bu göreve atanmıştır. ${ }^{59}$

Sonuç olarak Makkabiler siyasi erki elde etmelerine rağmen Başkohenlik makamına çıkmaları çok uzun sürmüştür. Makkabilerin bu makama çıkmalarının önündeki ilk engel muhtemelen onların Başkohenlik için gerekli asil bir soy kütüğüne sahip olmamalarıdır. Başkohenlik makamının gerçek sahibi Oniasların bu makama geçmesi beklenilmiş, Mısır'a kaçan Oniasların Başkohenlik makamına yeniden çıkma ihtimali ortadan kaldırılınca Makkabiler bu makamı işgal etmişlerdir.

\subsection{Haşmoniler ve Çift Başı Yönetim}

Haşmoniler soylarından kaynaklı gecikmeli ve bir konsey muvafakatinden sonra başkohenlik makamına çıkmışlardır. Ancak Haşmoniler, hiçbir zaman bu yetki ile yetinmemiş hatta yönetici-rahip eş başkanlığı anlayışıyla da mücadele etmek zorunda kalmışlardır. İsrailoğulları Mısır'dan çıkarken başlarında lider olarak Musa ve Harun bulunmaktadır. Bu iki liderli yönetim modelini kıstas almak daha sonraki zamanlarda Kral Davut'la beraber Başkohen Sadok'u veya Babil Sürgününden dönerken Şeşbassar'la (veya Zerubbabel) beraber Başkohen Yaddua'yı zikretmeyi gerekli kılmıştır. Monarşi yıllarında Sadok’un sade bir saray memuru olduğunu veya Şeşbassar'ın ve akabinde Zerubbabel'in kaynaklardan gizemli kayıp oluşlarını görmezden gelmek de Musa zamanında var olan yönetim modeline dönme isteğinden kaynaklanmaktadır. Haşmoniler ise bu isteği reddeder bir şekilde Yaratılıs kitabının

56 Yaddua'dan sonra oğlu I. Onias’ın (M.Ö. 320-280) Başkohenliğe gelmesiyle “Oniaslar” adını verebileceğimiz bir Başkohenlik hanedanlığından bahsedebiliriz. Öyle ki I. Onias’ın soyundan gelen yedi nesil Başkohenler Harun soyundan geldiği şüpheli olan Menelaos’un (M.Ö. 172-162) Başkohenliğine kadar iktidarda kalmış, da ha sonra bu hanedanlık mensupları Mısır’a iltica etmiştir. Oniaslar ismi ilk kaynaklarda yer almaz. Modern tarihçiler, Oniaslar ismini Tobiadlar ve Haşmonilerin yanında kullanmaya başlamışlardır (Buechler, Die Tobiaden und die Oniaden, 1899).

57 Josephus, Alkimus'un Onias ailesinden olmadığını ve Başkohenlikte bir hanedan değişikliği olduğunu söyler (bk. Josephus, The Antiquities of Jews 12:37; 20:235). II. Makkabiler kitabı ise Alkimus'u 14:7'den hareketle Oniaslardan görmektedir (Tcherikover, Hellenistic Civilization and the Jews, s. 227).

58 VanderKam, From Joshua to Caiaphas, s. 244-251.

59 I. Makkabiler 14:27. Burada Simon için kullanılan tabir Asaramel'dir. Ancak bu kelimenin kökeni tartışılmakla beraber genel anlamda Simon'un bir konsey tarafından 'Başkohen' olarak tanınması anlaşılmaktadır (Gafni, "Asaramel”, Encyclopedia Judaica, II, 544). 
gizemli kral-rahibi Melkisedek’i referans almış gözükmektedir. Yaratılış kitabında bir anda karşımıza çıkan Melkisedek, İbrahim’i kutsadıktan sonra kayıp olmuştur. Böylelikle Haşmoniler, iki liderli yönetim modeline büyük ataları İbrahim’i bile kutsayan bir kral-rahip bularak karşılık vermek istemişlerdir. ${ }^{60}$

Melkisedek modeliyle iki liderli yönetim anlayışına alternatif getiren Haşmoniler pratikte de siyasi ve dini erki bir elde toplamaya çalışmışlardır. Ancak bunda başarılı olamamış hatta her iki liderliği başkalarıyla paylaşmak durumunda kalmışlardır. Siyasi erki "Büyük Kurul” ile paylaşmış kral olmaya kalkıştıklarında, Davut soyundan gelmemeleri sebep gösterilerek meşru kral olarak görülmeleri engellenmeye çalışılmıştır. Diğer taraftan Selevkosların ihsanıyla Başkohenlik makamına çıkmış olsalar da "Nasi” ve "Av beyt din" unvanlı din adamlarının varlığı Haşmonilerin dini otoriteyi tam olarak ele geçiremediklerini göstermektedir.

Son haliyle bir tür şeri Yahudi Konseyi hüviyeti kazanan Sanhedrin'in tarihsel kökeni ve yapısı net değildir. ${ }^{61}$ Sanhedrin'le ilgili olarak Helenistik kaynaklarda ${ }^{62}$ kurulun lideri "Başkohen” olarak sunulurken, Rabbani Literatürde "Nasi” kurulun lideri, "Av beyt din” (Dini Mahkemenin Başkanı) ise kurulun ikinci adamı olarak gösterilmektedir. Araştırmacılar Başkohen, Nasi ve Av beyt din olmak üzere üç farklı unvanın ortaya çıkmasını Haşmonilerin Başkohen olmasıyla ilişkilendirmektedirler.

Solomon Zeitlin, Nasi ve High Priest (Başkohen) arasındaki ilişkiyi incelerken Sanhedrin tarihini de ele almaktadır. ${ }^{63}$ Ona göre sürgün sonrasının Başkohenleri toplumun aynı zamanda siyasi liderleri oldukları için seküler anlamdaki "Nasi” ismini almışlardır. Bu dönemde yazılmış olan Hezekiel kitabının 40-48. bablarında "Başkohen" tabirinin geçmemesinin sebebi de budur. Bu babları yazan kişinin Başkohen tabirinden habersiz olması mümkün değildir. Zeitlin’e göre Nasi ve Başkohen tabirleri aynı kişi için kullanılmakta ve Haşmonilerden Simon'un seçimle Başkohen olması Sanhedrin'in kurulmasına sebep olmaktadır. Simon'un Sadok soyundan olmaması ve Başkohenliği babadan devir almamış olması bir yetkisizlik olarak algılanmış ve bu yetki Sanhedrin’le doldurulmaya çalışılmıştır. Böylelikle

60 Regev, The Hasmoneans Ideology, Archaeology, Identity, s. 172-173.

61 Yunanca "sunédrion” kelimesinden türetildiği düşünülmektedir. Yunanca konuşan Yahudiler arasında Sanhedrin'in gerousía (İhtiyar Meclisi/The Assembly of the Ancients) ismi daha yaygındır. Beth-Din (Hüküm Evi/House of Judgment) kelimesi de sürgün sonrası dönemde belirginleşen diğer ismidir. Grekçe olan bu kelime oturum anlamına gelmektedir. Sanhedrin, Yahudi genel inanışında dinsel yasama ve yargılamanın yapıldığı kurul veya mahkeme anlamında kullanılmaktadır. Yetmiş bir üyeden oluşan bu kurula Nasi (Prens) başkanlık etmekte olup ikinci makamda "Av beyt din" (Mahkeme Başkanı/Father of the Court) diyebileceğimiz ikinci bir başkan bulunur. Diğer üyelerine ise "Mufla" denir. Üyelik kalıcı olmakta yani ömür boyu bu üyeliğe atanmakta ve bu üyeler de Kohenler, aristokratlar ve din bilginlerinden meydana gelmektedir. Muhtemelen de alt mahkemelerin ileri gelenleri bu mahkemeye yükseltiliyordu. Bir üyenin ölmesi üzerine kurul yeni bir üye atamaktadır. Mabed’de toplanan kurulun almış olduğu kararlar yargılama konusundaki nüfuz alanı, Yehuda bölgesiyle sınırlı kalsa da ahlaki konulardaki kararları diğer bölge Yahudileri tarafından titizlikle yerine getiriliyordu. Mabed’e bayram için gelen Yahudiler bulundukları bölge ile Sanhedrin arasında bir köprü kurmaktadır.

62 Mantel, "Sanhedrin", Encyclopedia Judaica, XVIII, 21.

63 Zeitlin, "The Titles High Priest and the Nasi of the Sanhedrin", s. 1-5. 
Başkohenin unvanı Nasi bu kurulun başkanına verilmiştir. Sonuç olarak Zeitlin’e göre Haşmoni Başkohenleri, Nasi unvanı alamadıkları için, Başkohenlik yanında Nasi ve Av beyt din önderliğinde üçlü bir dini yönetim sağlanmıştır. ${ }^{64}$

Benzer şekilde Haşmonilerin Başkohen olmalarındaki meşruiyet sorunu, Sanhedrin'deki Nasi ve Av beyt din unvanları adı altında çift başlı yapının varlığının sebebi olarak gösterilmektedir. Buna göre Makkabiler zamanında Başkohenliğin sekülerleşmesi Sanhedrin'de ruhani bir lidere ihtiyaç duyulmasına sebep olmuş ve dini konulardaki sorunları çözmesi için bir tür hocalık/babalık anlamında Sanhedrin'de Av beyt din adında ikinci bir başkanlık ihdas edilmiştir. ${ }^{65}$

Ayrıca Haşmonilerin dini alanda tek otorite olmadıklarının diğer bir göstergesi bugünkü Rabbilerin ilk modelleri olan Zugotlar'ın ${ }^{66}$ Başkohenliğin yanında yer almaya başlamasıdır. Beşli bir silsile olan eş başkanlı Zugotlardan her biri Nasi ve Ab Beyt Din unvanını almıştır. Yuhanna Hirkanus, ikinci eş başkanlar Joshua b. Perahyah ${ }^{67}$ ve Arbelli Nattai'ye baskı uygulamış, ancak Alexandra’nın kraliçe olmasıyla üçüncü eş başkanlardan itibaren Zugotlar yeniden Sanhedrin'de söz sahibi olmaya başlamışlardır.

Haşmoniler siyasi erki de bir takım sınırlamalarla elde etmişlerdir. Bu hanedan, başkaldırı lideri olmaktan sırasıyla etnarklığa daha sonra da krallığa ${ }^{68}$ ulaşmıştır. ${ }^{69}$ Ancak siyasi ve askeri başarılarına rağmen kendilerini kral ilan ettikleri zaman Davut soyundan gelmedikleri sebep gösterilerek yasal sınırlarına çekilmeye zorlanmışlardır. Haşmonilerin yönetimde Büyük Kurul'un ${ }^{70}$ varlığı ve ondan bağımsızlaşma teşebbüsleri döneme ait nümizmatik delillerle desteklenebilir.

64 Zugotların da Nasi ve Av beyt din unvanları aldığını söyleyen Zeitlin, daha sonraki din adamlarının unvanı olan Rabbi (Prens) kelimesinin de kökenini Nasi'ye bağlar. Zeitlin, “The Titles High Priest and the Nasi of the Sanhedrin”, s.5.

65 Jacobs-Kohler, “Nasi”, Jewish Encyclopedia, IX, 171.

66 Hazal denilen din adamları grubunun ilk halkasını eş başkanlar diyebileceğimiz Zugotlar oluşturur. Unvanları, çift anlamındaki İbranice Zugot kelimesinden gelir (Encyclopedia Judaica, "Zugot”, XXI, 680). Beş nesilden oluşan bu ilmi silsile Jose ben Joezer ve Jose ben Jochanan ikilisinden başlamakta Hillel ve Şammai ikilisiyle son bulmaktadır. Mishnah Avot 1:4-1. Bu çiftin Sokho'lu Antigonus'un öğrencileri oldukları sanılmaktadır. Bu ilmi zincire göre Adil Simon'un ilmi veraseti öğrencisi Sokho'lu Antigonous’a geçmiştir. Zugotlar bu ilmi zincirde hocalarıyla Tannaimlerin meşhur âlimi Johannan b. Zakai arasındaki köprüyü oluşturmaktadır.

Hatta Joshua, Hirkanus'un Ferîsîler üzerine uyguladı̆̆ı baskı döneminde İskenderiye’ye iltica etmiştir (SingerLauterbach, "Joshua b. Perahyah", Jewish Encyclopedia, VII, 295).

68 Josephus'a göre Kral unvanını alan ilk Haşmoni I. Aristobulus iken Strabo’ya göre ise bu kişi onun oğlu Alexander Yanay'dır (The Antiquities of the Jews, 13. 301; a. mlf. , The Wars of the Jews, 1. 70). Ayrica bk. Schalit, "Aristobulus I", Encyclopedia Judaica, II, 457.

69 Dabrowa, Haşmoni Krallı̆̆ı için üç önemli olay sayar. Bunlardan ilki Yonathan’ın M.Ö. 152'de Alexander Balas tarafından Başkohen olarak tanınmasıdır. İkincisi ise Simon'un M.Ö. 140 yılında Büyük Kurul tarafından hem dini hem de seküler lider olarak tanınmasıdır. Üçüncüsü ise I. Aristobulus'un kendini kral ilan etmesidir (The Hasmoneans and Their State, s. 85).

70 Yöneticinin yanında bir kurulun varlığı Yahudi toplumunun aşina olduğu bir durumdur. Musa zamanında Tanrı, Musa'dan 70 kişi seçerek onları Buluşma Çadırı'na çağırmıştır. Bunun amacı Musa’nın üzerindeki yükü hafifletmektir (Sayılar 11:16-17). Yine Kral Yehoşafat, Küdüs'te bazı davalara bakması için Levilileri, Kohenleri ve boy liderlerini atamıştır (II. Tarihler 19:8). Ezra ve Nehemya kitaplarında da bu iki yöneticinin yanında buna benzer bir kurulun varlığından söz edilmektedir (Ezra: 5:5, 9; 6:7, 14, 10:8; Nehemya 2:16; 4:13; 5:7). Bu kurula "Büyük Sinagog", 
Yuhanna Hirkanus, Haşmoni paralarını ilk basan yöneticidir. ${ }^{71}$ Halk dili Aramice olmasına rağmen paraların İbranice basılması Haşmonilerin Davut Hanedanlığının yeni varisleri olduklarını ilan etme ve milliyetçi bir mesaj vermeye çalıştıkları şeklinde yorumlanmaktadır. ${ }^{72}$ Paraların bir yüzünde "Başkohen Yuhanna Hirkanus" ibaresi yer alırken diğer yüzünde "Büyük Kurul” veya "Büyük Kurul’un Başı" ibareleri yer almaktadır. Bu durum Haşmonilerin Yahudi toplumunun tek hâkimi olamadıklarını en büyük göstergesidir.

Alexander Yanay zamanında basılan paralardaki değişim onun krallığının açık bir ilanıdır. Çift dilli (Grekçe-İbranice) basılan bu paralarda "Başkohen” ibaresi yerini "Kral" unvanına bırakmıştır. Paraların üzerindeki “yıldız”, Sayılar 24:17’ye ${ }^{73}$ bir referans olarak yorumlanmakta ve Haşmoni monarşisinin ilanı olarak görülmektedir. ${ }^{74}$ Paralara da yansıyan bu yönetim değişikliğinin ilanı beraberinde Haşmoni Krallığında bir iç savaşa neden olmuştur. Haşmoni Krallığı, iç savaşlarla ve halktan gelen desteğin kayıp olmasıyla Alexander Yanay’n oğullarının taht kavgasından sonra yıkılmıştır.

Amcası II. Hirkanus’a karşı savaşan II. Antigonus, paraların bir yüzüne yeniden Başkohen ve Büyük Kurul ibareleri bastırmış ${ }^{75}$ olsa da Haşmoniler tahtlarını zorla Yahudileştirdikleri Edomlu Herod’a bırakmak zorunda kalmıştır. Alexander Yanay’ın kendini kral ilan etmesi Helenleşmekte olan Haşmoni krallığına karşı muhalefetin dini söylemini belirlemiştir. Böylelikle muhalefetin Helenleşmekte olan krallığa karşı çıkması Levili olan Haşmonilerin, Davut'un varisi olamayacakları üzerine temellendirilmiştir.

Sonuç olarak Haşmoniler, lider ve rahip şeklindeki iki liderli yönetim anlayışını değiştirmek istemiş ama başarılı olamamışlardır. Bunun ötesinde Başkohenlik makamına gelişleri ve

İbranice "Keneset ha-Gedolah" denir. Bu kurulun peygamberlerden sonra ilmi bir zincir oluşturulduğu ve dini bilginin Musa'dan itibaren aktarıldığı kabul edilir. Bu kurulun ilk şeklinin Ezra ve Nehamya zamanında ortaya çıtı̆̆ varsayılmaktadır. Nehemya'dan (Nehemya 8:1-18) hareketle 85 kişi olan bu kurul üyelerinin 120 sayısına çıkartmak için bazı yorumlar yapılmaktadır (Megilah 17b). Bu kurulun Haşmoni devrinde Simon’u Başkohen seçen kurul olduğu, Simon’un da bu bağlamda adı geçen "Adil Simon" olduğu veya yine II. Mabet döneminin ürünü olan Sanhedrin’in ilk halinin bu kurul olduğu iddia edilmektedir. Ancak bu iddialar bir takım kronolojik problemlerle karşı karşıyadır (Sperber, “Great Synagogue”, Encyclopedia Judaica, XIX, 382-383). Sanhedrin’in ilk şeklinin Musa veya Ezra’nın Büyük Kurul’a dayandırmak pek gerçekçi değildir (ayrıca bk. Kurt, Ezra Önderliğinde Yahudiliğin Yeniden Yapılandırılması, s. 212-213). Kanımızca Sanhedrin'in Büyük Kurul adı altında bir tür senato iken Yahudi Din Konseyi’ne dönüşmesi, Sanhedrin’e Musa ve Ezra zamanında tarihsel kökenler arama çabası veya bu kuruma sadece Ferîsîlerin gözünden bakılması onun gerçekte nasıl bir kurum olduğunu anlamamızı zorlaştırmaktadır.

71 Hendin, "Numismatic Expressions of Hasmonean Sovereignty", s. 83.

72 Hendin, "Numismatic Expressions of Hasmonean Sovereignty", s. 85.

73 "Onu görüyorum, ama şimdilik değil,

Ona bakıyorum, ama yakından değil,

Yakup'tan bir yıldız çıkacak,

İsrail'den bir önder yükselecek,

Moavlılar'ın alınlarını,

Şetoğulları'nın başlarını ezecek. ”

74 Hendin, "Numismatic Expressions of Hasmonean Sovereignty", s. 88.

75 Paraların üstündeki Mabet motifleri ve adaşı olduğu Makkabi isyanının başlatan Matatiyas ismine yer vermesi yıkılmakta olan krallığın özüne döndüğü mesajları taşır (Hendin, "Numismatic Expressions of Hasmonean Sovereignty", s. 90). 
krallğ̆a talip oluşları Yahudi kültüründe var olan soy ayrıcalığı ve üstünlüğü kriterlerine uymadığ 1 için bu erklerini paylaşmak durumunda kalmışlardır. Dini alandaki erki Nasi ve Av Beyt din ile paylaşmışlardır. Siyasi anlamda da Büyük Kurul'dan bağımsızlıklarını ilan ettiklerinde de soya dayalı bir muhalefet söylemi ile karşılaşmışlardır. Oniaslar'dan itibaren Başkohenlik makamının Haşmoniler tarafından doldurulması bir türlü sindirilememiş, kendilerini kral ilan ettikleri anda ise dini söylemler muhalefet aracı olarak kullanılmıștır. Krallık güçlü olduğu yıllarda muhalefeti şiddetle bastırılmış olsa da bu iç savaşlar krallı̆̆ın sonunu hazırlamıştır.

\section{Haşmoni Soyunun Saflığını Kaybettiği İddiası}

Kohen, doğuştan gelen soyun saflığına sahip olmakla beraber bunu devam ettirmek durumundadır. Kohen, dul bir kadın ile evlenemez. ${ }^{76}$ Aksi takdirde soyunun saflığ bolacaktır. Öyle ki artık o rahiplik yapamayacağı gibi soyundan gelenlerde rahiplikten azil edilmiş olacaktır. Yine esir düşmüş bir annenin çocuğu da Kohenlik için gerekli olan soy saflığını kaybetmiş olmaktadır. Yuhanna Hirkanus’un krallığa giden yolda izlemiş olduğu politikalar, ilk önce Helenizm karşısında yanında yer alan müttefiklerini rahatsız etmiştir. Neticede Ferîsîler Haşmonilerin, bir Kohenin sahip olması gereken soy saflığını kaybetmekle suçlamışlardır. Talmud'da ${ }^{77}$ ve Josephus'un kitabında bununla ilgili bir rivayet bulunmaktadır. Olayın hangi Haşmoni lideri zamanında yaşandığı ve Elezar’ın kim olduğu konularında rivayetler arasında farklılık olsa her iki rivayetin ortak noktası Haşmoni kralının böyle bir suçlamayla karşı karşıya kalmasıdır. ${ }^{78}$ Josephus'taki rivayete göre Elezar isminde bir kişi Yuhanna Hirkanus’a Başkohenlikten el çekmesi gerektiğini söylemiştir. Zira annesinin IV. Antiyokus zamanında esir düştügü dolayısıyla da Başkohenin sahip olması gereken saflı̆̆ı kaybettiğini söylemiştir.

Yuhanna Hirkanus'un veya Alexander Yanay'in Ferîsîler tarafından bu tür bir ithamla karşılaşmaları oldukça manidardır. Zira her iki Haşmoni liderinin uygulamaları, ataları Simon zamanında Yahudi grupları arasında sağlanmış olan konsensüsü bozmuş görünmektedir. Yuhanna Hirkanus Helen bir kral gibi davranmakta, paralı asker ihtiyacını karşılayabilmek için Davut'un kabrini yağmalamakta veya Edomluları zorla Yahudileştirmekte bir beis görmemektedir. Dolayısıyla Haşmoni kralına karşı yükselen bu muhalefet Yahudi toplumundaki soy ayrıcalığını üzerinden ifade edilmiştir. Ferîsîler muhalefet söylemlerini Haşmonilerin övündükleri husus olan soyun ayrıcalığı üzerinden yaparak onları zayıflatmak istemişlerdir.

Kohenin soyunun saflığını koruması bağlamında ele alınması gereken oldukça karışık diğer bir husus I. Aristobulus'un bir yıllık krallığından sonra ölmesiyle dul eşi Salina 
Alaksandıra ile hapisten çıkarttığı kardeşi Alexander Yanay’ın evlenmiş olduğunun tartışılmasıdır. Böyle bir evlilik gerçekleşmiş ise iki evlilik kuralı çatışmakta ve Levirate (Kayınbirader-Yenge) evliliğinin, Kohenin dul bir kadın ile evlenemeyeceği sınırlamasına tercih edilmiş olduğu görülmektedir. Modern tarihçiler, Salome Alexandrảnın, I. Aristobulus'un dul eşi Selina Alexandra olmadığını temellendirerek konuyu kısa yoldan bir çözüme kavuşturmuşlardır. ${ }^{79}$ Ancak Alexander Yanay'ın, ölen kardeşinin dul eşiyle evlenmiş olduğunu varsayarsak Ferîsîlerin Alexandır Yanay’ın bu evliliğine niçin itiraz etmemiş olduklarına bir yorum getirmek istiyoruz. Hâlbuki bu dönemde soyun saflı̆̆ını korumaya ve görev liyakatini kaybetmemeye büyük önem verilmektedir. Öyle ki II. Antigonus'un, amcası II. Hirkanus'un Başkohenlik makamına liyakatini kaybetmesi için kulağını 1sırarak kopardığı rivayet edilmektedir. ${ }^{80}$ Çünkü fiziki kusur bir Kohenin bu makama gelmesi için engel teşkil etmektedir. Her fırsatta Haşmonilerin Başkohenliğinin meşruiyeti sorgulandığı bir ortamda niçin bu evlilik söz konusu edilmemektedir? ${ }^{81}$ Kanaatimizce böyle bir evliliğin Ferîsîlerin, Haşmonilerin aleyhinde kullanmamasının bir sebebi vardır. Zira Levirate evlilik, Helen dünyasının etkisinde ${ }^{82}$ kalan Sadûkîlerin karşı çıktığı bir evliliktir. ${ }^{83}$ Alexander Yanay, böyle bir evlilik gerçekleştirmek suretiyle Sadûkîler karşısında yer almış ve Ferîsîleri desteklemiş olacağından bu konu polemik konusu yapılmamıştır denilebilir. ${ }^{84}$

Sonuç olarak Haşmonilere, Yuhanna Hirkanus ve Alexander Yanay zamanında Makkabi isyanındaki müttefikleri olan geleneksel Yahudiler tarafından yapılan ilk suçlama onların bir Kohenin taşıması gereken soy saflığını kaybettikleridir. Geleneksel Yahudilerin Simon’un Başkohenliğine rıza göstermeleri, Haşmonilerin ikinci ve üçüncü neslinde tersine dönmüş ve onlardan bu makamı bırakmaları istenmiştir.

\section{Haşmonilerin Zorla Yahudileştirme Politikasının Teolojik Ve Siyasi Yansımaları}

Haşmoni hanedanlığının krallaşma yolunda uyguladığı Yahudileştirme politikası yine soyla ilgili olarak teolojik ve siyasî yansımaları olan bir husustur. Bu yayılmacı politika Yahudi grupları arasındaki görüş farklılıklarına yeni bir konu başlığı kazandırmıştır. Yine

79 Modern tarihçilerin hareket noktası Josephus'un bu iki kraliçenin aynı kişi olduğunu açıkça belirtmemesidir (Tal, "Queen Salamzion Alexandra and Judas Aristobulus I’s Widow", s. 181-90). Buna rağmen Salina Alexandra ile Salome Alexandra aynı kişi olduklarının varsayımın arkasında Ferîsîlerin hamisi Salome Alexandra’yi oldukça nüfuzlu bir kraliçe gösterme çabası olabilir.

80 Josephus, The Antiquities of the Jews, 14. 330; a.mlf., The Wars of the Jews, 1. 248

81 Bu durumu izahata kavuşturmak için Alexander Yanay bu evliliği yaptıktan sonra Başkohen olmuştur veya Kohenin Levirate evliliğinden muaf olduğu daha sonra meşrulaşmıştır şeklinde açıklamalar yapılmaktadır.

82 Atkinson, Queen Salome, s. 63.

83 Ginzberg, "Alexander Jannæus (Jonathan)", Jewish Encyclopedia, I, 352.

84 Ayrıca Ferîsîlerin bakirelik ve Levirate evlilik konusunda itidal ve akl-ı selimle hüküm vermeye çalıştığı bilinmektedir (Kutluay, İslâm ve Yahudi Mezhepleri, s. 222). Dolayısıyla bu saikle de Ferîsîler bu evliliği muhalefet konusu etmemiş olabilirler. 
Haşmoni hanedanlığının sonunun Yahudileştirilmiş bir Edomlu olan Herod tarafından hazırlanması da ironik bir durumdur.

\subsection{Zorla Yahudileșenlerin Durumu Hakkında Sadûkîler ve Ferîsîler Arasındaki} Fikir Ayrılı̆̆ı

Haşmoni Krallı̆̆ı, Sadûkîler, Ferîsîler ve Essenîler gibi Yahudi gruplaşmalarının belirginleştiği bir dönemde tarih sahnesine çıkmıştır. Haşmoni Krallığının iktidarına sırayla ortak olan Sadûkîler ve Ferîsîler arasındaki farklılığı ortaya çıkaran temel faktörün ne olduğu birçok araştırmacı tarafından ele alınmıştır. ${ }^{85} \mathrm{Bu}$ araştırmacılardan Zeitlin, Ferîsîlerin tarihini II. Mabed'in yapım zamanına kadar geri götürür. ${ }^{86}$ Ona göre Ferîsîler, Yahve’nin sadece İsrailoğullarının değil aynı zamanda bütün insanların tanrısı olduğunu iddia etmektedirler. İkinci olarak onlar Mabed’in “Tanrı'nın Evi” olarak isimlendirilmemesi gerektiğini zira Tanrìnın her yerde olduğunu benimsemektedirler. ${ }^{87}$ Yine Zeitlin’e göre "seçilmiş millet” düşüncesi Sadûkîlere aitken; Ferîsîler "seçilmiş din" anlayışını savunmaktadır. Ferîsîlerin bu etnik

85 Abraham Geiger, Sadûkîlerin muhafazakâr ve statükocu olup geleneksel kanadı temsil ettiğini, Ferîsîlerin ise bunun karşısında gelişmelere açık olup liberal kanadı temsil ettiğini söyler. Wellhausen ise Sadûkîleri, içinde Haşmonilerin, Kohenlerin ve asillerin olduğu, Herod veya Roma gibi devletlerin hükümdarlığını istemeyen, bağımsızlığı ön plana alan politik bir grup olarak görür. Ona göre Ferîsîlere politik bir grup demek mümkün değildir. Ferîsîler politik konulara girmeksizin Yahudi şeriatına ve toplumuna bağlı dini bir mezheptir. Ferîsîler üzerine çalışmalarıyla tanınan Louis Finkelstein ise bu iki ana düşünceyi yansıttıktan sonra belki de döneminin etkisiyle Marksist bir yaklaşımla bu iki grup arasındaki farklılığın sebebini toplumsal farklılıklarda aramaktadır. Ona göre Sadûkîler toprak sahibi olan kırsal bölge halkı iken; Ferîsîler kentli Yahudiler idi. Daha sonra Ferîsîler ölümden sonraki hayat ve demokratik yaklaşımlarıyla kırsal kesimden birçok taraftar bulmuş, Sadûkîler ise zengin ve imtiyaz sahibi küçük bir grup olarak kalmıştır. Finkelstein’a göre Alexander Yanay’ın, Sukot bayramında suyu yere veya kurban üzerine dökmesinin bir anlamı vardır. Rivayete göre Alexander Yanay Sukot bayramında sunakta mezhepsel bir ayrımda taraf tutmuştur. Ferîsîlerce altara dökülmesi gereken suyu Sadûkîleri desteklercesine ayaklarına dökmesi halk tarafından yuhalanmasına sebep olmuştur. Bu hareketini müteakiben halk, bayramda kullandıkları ağaç kavunlarını (İng. citron) onu protesto etmek için kullanmıştır. O da halkın üstüne askerlerini göndererek protesto gösterisine kan dökerek cevap vermiştir. Alexander üç bin Ferîsîyi öldürmekten geri durmamıștır. Ona göre Sukot, Sadûkîler ve Ferîsîler için farklı anlamlar yüklü bir bayramdır. Sadûkîler, Sukot'u sadece bir hasat bayramı olarak görmektedirler. Ferîsîler ise Sukot'u bir kurban ve su ritüeli olarak görmektedirler. Onu bir su ritüeli görmelerinin sebebi, bu dönemde kentli Yahudi’nin suya olan gereksinimden kaynaklanmaktadır. Finkelstein herkesin aklına gelebilecek soruyu kendisi sormaktadır. Toprak sahibinin suya ihtiyacı daha fazla değil midir? Sadûkîler Tanrı’nın gelecek kaderini sadece 'Kefaret Günü’ne hasretmekte ve o günün kutsiyetine zarar vermeden Sukot'u sadece bir hasat bayramı olarak görmektedir. Ferîsîler ise bunun aksine Tanrı’nın takdirini Kefaret Günü, Fısıh, Sukot ve Haftalar Bayramı şeklinde dört döneme çıkarmış bulunmaktadır. İște Alexander Yanay suyu yere dökerek Ferîsîlerin Sukot'a yüklemiş oldukları Tanrı'nın su takdiri dönemi fikrine saldırmıştır. Yine Finkelstein göre Sadûkîler ulusçuluk fikrini savunurken Ferîsîlerde bireyselcilik hâkimdir. Ferîsîlerin Yahudi ulusunu bağımsız kılma gibi bir ülküleri bulunmamaktadır. Bağımsızlıklarını kaybetmiș olsalar da onların öncelik vermiş olduğu prensip Yahudi şeriatına bağlllıktır. Savaşmaksızın şehri düşmana teslim etmeleri veya Haşmoniler için Selevkoslardan yardım istemeleri anlayışının neticeleridir (Finkelstein, "The Pharisees", s. 185-187; Josephus, The Antiquities of the Jews, 13. 372; Zeitlin, "Queen Salome and King Jannaeus Alexander", s. 14).

86 Zeitlin, Ferîsîleri 'ayrılıkçılar’ olarak niteler ve Ferîsî kelimesini Sadûkîler karşısında yer alan grubun bir lakabı olduğunu düşünür. Ona göre Ferîsîler, Davut soyundan gelen Zerubbbabel'in liderliğinde sivil bir teşkilatlanma taraftaları iken; Sadûkîler Başkohen Yeşu’nun takipçileri ve dini temelleri olan yeni bir toplum yapısını arzulayanlardır. Zeitlin, “The Origin of the Pharisees Reaffirmed", s. 256.

87 Zeitlin, “The Origin of the Pharisees Reaffirmed”, s. 267; a.mlf., “The Pharisees: A Historical Study”, s. 129. 
yapıdan kurtularak evrenselliğe geçmeleri, diğer etnik tanrılarda olduğu gibi Yahve'yi tarih sayfalarında kaybolma akıbetinden kurtarmıştır.

Ferîsîler, yaptıkları yenilikler ile Yahudiliği seçkin bir zümre dini olmaktan kurtarıp onun halkın dini olmasını sağlamaya çalışmışlardır. Kohenlere has adetleri halka intikal ettirmiş, ${ }^{88}$ Sinagoglardaki Tevrat öğretimiyle halka ulaşmışlardır. ${ }^{89}$ Yine Ferîsîler, Kohenlerin Mabed'deki imtiyazlarını sınırlandırmaya çalışarak halkı Mabed’e yakınlaştırma çabası içinde olmuşlardır. ${ }^{90}$

Teolojik, politik konularda birbirinden farklı düşünen bu iki Yahudi grubunun arasındaki diğer bir fikir ayrılığı Yahudiliği kabul edenlerin durumu hususundadır. Seçilmiş Millet'i savunan Sadûkîler ve Seçilmiş Din anlayışını benimseyen Ferîsîler arasında fikir ayrıllğının bir yansıması Haşmonilerin zorla Yahudileştirme politikasında kendini göstermektedir. "Kutsal Soy" 91 anlayışı II. Mabed ve sonrasında Yahudi toplumunda sosyal statü belirleyicisi olmuştur. Mabet hizmetindeki ayrıcalıkları ve toplumun bu ayrıcalıklı sınıf tarafından yöneltilmesi elit bir Yahudi zümresinin oluşmasına sebep olmuştur. Bu seçkin zümre bazı ayrıcalıklarla kendini sıradan Yahudilerden ayırmaktadır. Dar milliyetçi anlayışta olan Sadûkîler, zorla Yahudileştirilen bu kavimlerin ikinci sınıf "Yarım Yahudi" olduğunu düşünmektedirler. Sadûkîlerin aristokrat bir zümre oldukları ve sınıf ayrımı gözettikleri özellikle de Yahudileştirilenlere karşı ayrımcılık yaptıkları bilinmektedir. ${ }^{92}$ Diğer taraftan Ferîsîler ise zorla Yahudileştirme politikasına karşı çıkmakta ve bu politikanın Yahudiliği yozlaştırdığını düşünmektedirler. Ancak Ferîsîler, bu kavimlerin soylu Yahudilerden bir farkları olmadıklarını savunmaktadırlar. Ferîsîlerin takipçileri olan Rabbinik Yahudiliğe miras kalan "Bilgili olan bir Mamzer (gayrı meşru çocuk) bilgisiz bir Başkohenden üstündür" ${ }^{93}$ sözü bu durumu özetlemektedir.

Ferîsîler, Yahudiliği evrensel bir din olarak kabul ediyor ve yabancılara kapıları açıyorsalar da, Haşmoniler ile olan mücadelelerinde eleştirmiş oldukları dar milliyetçilik anlayışına kapılmış veya gelecek dönemin bu minvalde yol almasına sebep olmuşlardır. Ferîsîlerin muhalefet ederken kullanmış oldukları "Kral Davut soyundan olmalıdır" söylemi daha sonraki dönemlerin tartışılmaz bir ilkesi olarak yerleşecektir. Öyle ki Mesih iddiasında olan herkesin Davudi bir şecere arama zorunda kalması, Ferîsî ve Sadûkî mücadelesinden Ferîsîlerin

88 Bir Ferîsî kendi günlük yiyeceklerinin koşerliğine tıpkı Mabed’deki Kohen kadar itina göstermekteydi. Diğerleri için bk. Kutluay, İslâm ve Yahudi Mezhepleri, s. 220

89 Kutluay, Ferîsî hareketinin halk arasında büyük ölçüde taraftar kazanmasını sinagogların tesisine bağlar (İslâm ve Yahudi Mezhepleri, s. 219).

90 Sadûkîlere bağlı Kohenlik, Mabed’i kendi malı gibi görürken Ferîsîler, halkın hazineye bağışta bulunduğu için Mabed'in kimsenin öz malı olmayacağını savunmaktadır. Bu sebeple Ferîsîler mezbahta kesilen kurbanın halka verilmesi gerektiğini ileri sürmektedirler (Kutluay, İslâm ve Yahudi Mezhepleri, s. 221).

91 Sürgün döneminde ortaya çıkan 'Kutsal Soy (Holy Seed/Kutsal Döl)' kavramı ve Adem'den Kohenlere uzanan bu soyun Tanah’ın arka planına yerleştirilmesine bir diğer makalemizde yer vereceğiz.

92 Sadûkîler Yahudileştirilen bu zümreyi alt tabaka olarak görmektedir (Zeitlin, "Queen Salome and King Jannaeus Alexander", s. 26).

93 Mişna, Horayoth 3:8, 
galip çıkmasından kaynaklanmaktadır. Davut soyundan bir kurtarıcı beklentisinin Ferîsîler tarafından yeniden alevlendirilmesi, etnik üstünlügün önem kazandığı bu dönemde karşı bir hamle olarak görülebilir. Onlar, Haşmonilerin rahiplik sınırına çekilmelerini, krallığı Davut soyuna ${ }^{94}$ bırakmaları gerektiğini söylemeye çalışmışlardır. Ferîsîlerin ve diğerlerinin Haşmonilerle sık sık soy münakaşasına girmelerinin arkasındaki sebeplerden bir tanesi, muhtemelen Haşmonilerin çok güvendikleri soy üstünlügüüü boşa çıkarmaya çalışmaktır. Ana sebep ise muhtemelen Haşmonilerin geleneksellikten uzaklaşarak gitgide Helenleşmiş olmalarıdır. Yoksa Haşmoni zamanında kazanılan topraklar Süleyman zamanındaki sınırlarla hemen hemen aynıdır. Haşmonilerin başarılarını sırf Davut soyundan gelmedikleri için görmemek, beklenen krallığ 1 ileride Davut soyundan gelecek olan bir meçhul krala birakmak düşüncesi anlaşılacak gibi değildir.

Sonuç olarak Ferîsîler, evrensel bir din anlayışını benimsemiş olsalar bile İncilleri, Makkabiler kitabından soy kütükleri açısından farklı kılan sadece kutsal soyun değişmesidir.

\subsection{Soyun Ayrıcalığı Ekseninde Büyük Herod ve Vaftizci Yahya}

Büyük Herod ve varisleri krallıklarının meşruiyeti konusunda Haşmoni kanını önemsemişlerdir. Yehuda bölgesinde iktidarı ele geçiren Edomlu Herod (Büyük), Haşmoni hanedanlığının mirasına konabilmek için bu soydan gelen I. Meryem’i ikinci eş olarak alır. ${ }^{95}$ Herod, Mısır’n siyasi desteğini alan kayınvalidesi Alexandra ve karısı I. Meryem'in baskısı sonucu kayınbiraderi on yedi yaşındaki III. Aristobulus'ü Başkohen yapmak zorunda kalmıştır. Herod bir suikast ile III. Aristobulus'ü öldürdükten sonra sırayla I. Meryem ve kayınvalidesi Alexandra’yı da infaz ettirmiştir (M.Ö. 29). ${ }^{96}$ Herod, Mısırdan gördüğü siyasi baskının acısını Haşmoni ailesine kanlarıyla ödetmiştir. III. Aristobulus'un ölmesiyle Haşmoni hanedanlığının son erkek üyesi de ortadan kaldırılmıştır. Herod'un taht bunalımlarından Haşmoni kanı taşıyan oğulları da kurtulamamıştır. Herod, I. Meryem'den olma oğulları, III. Alexander ve IV. Aristobulus'ü M.Ö. 7 yılında öldürtmüştür. ${ }^{97}$

Büyük Herod'un izinden giden oğulları da Haşmoni kanı taşıyan kadın üyelerle evlenmeyi adet haline getirmişlerdir. Haşmoni kanı taşıyan kadın üyelerle evlilik, Herod Krallığı’nın tahtına çıkış için bir liyakat olarak algılanmıştır. IV. Aristobulus'un kızı, III. Meryem

94 Davut'un İsrailoğullarının tarihindeki rolü ve krallığışüphesiz önemlidir. Ancak Davut soyu üzerinde krallığın koşulsuz ve ebedi kalacağı fikri hem Kitabı Mukaddes'te hem de vakıada net değildir. Yehuda soyunun Yakup’un vasiyetinde krallık asasına sahip olacağı bir kehanet olarak bildirilmektedir. Ancak unutulmamalıdır ki İsrailoğullarının ilk kralı Bünyamin ailesinden Saul'dur. Davut soyunun ebedi olarak üstlendiği bu görev de zaman zaman kesintiye uğramıştır. Yeremya ise Davut soyunun bir kolunun bu meziyeti kaybettiğini vurgulamaktadır.

95 Büyük Herod soy üstünlüğü kazanabilmek için birçok evlilik yapmıştır. Herod Samirilerin desteğini alabilmek için bir evliliğini Samiri Matthace ile yapmıștır (Josephus, The Wars of the Jews, 1. 240). Bir diğer evliliğini Haşmonilerin yerine getirdiği Başkoken Simon Boethus'un kızı II. Meryem ile yapmıştır.

96 Makkabi Alexandra, kuzeni Yahudalı Alexander ile evlenmiştir. I. Meryem ve III. Aristobulus’un anneleridir. Damadı Büyük Herod tarafından öldürülmüştür (Milwitzky, "Alexandra”, Jewish Encyclopedia, I, 358-359).

97 Herod'un yine Haşmoni kanı taşıyan II. Meryem'den olan Salampsio ve Cypros isminde iki kızı vardır (Josephus, The Antiquities of the Jews, 18. 130). 
ilk önce üvey amcası II. Antipater'le nişanlanmış ${ }^{98}$ daha sonra diğer üvey amcası Herod Archelaus (M.Ö. 23-M.S. 18) ile evlenmiştir. ${ }^{99}$ II. Antipater de daha sonra Haşmonilerin son kralı Antigonus'un kızıyla evlenmişse de, bu kızın ismi bilinmemektedir. ${ }^{100}$

Yine aynı şekilde iki üvey amcasıyla evlenen IV. Aristobulus'un bir diğer kızı Herodias'tır. Herodias ilk önce II. Herod'la daha sonra ise Herod Antipas ile evlenmiştir. Herodias'in boşanmayı düşündüğü eşi, Büyük Herod'un, II. Meryem'den olan oğlu II. Herod’tur. Büyük Herod ölümüne yakın bir zamanda II. Meryem’i saraydan uzaklaştırmış ve babasını da Başkohenlikten azletmiştir. II. Herod da annesinin ölümü ve dedesinin azlinden sonra böyle bir boşanmayla veliahtlıktan uzaklaştırılmıştır. Bu minvalde Herodias da itibar kaybeden bu aileden diğer bir veliahtta yönelmiş olmalıdır. Herodias’in Antipas'la ikinci evliliğini yapması Sâmirî anneden olan Antipas’a bölgesel yöneticiliğin kapısını açmıştır. Antipas Samiriye bölgesinin tetrark’’ (ülkenin dört parçaya bölünmesi ile her bir parçanın yöneticisine verilen unvan) olmuştur.

Herod Antipas, Hristiyan tarihi açısından oldukça önemli bir yere sahiptir. İsa ve Vaftizci Yahya onun zamanında yargılanmıştır. Hatta Vaftizci Yahya’nın, Herod Antipas ile Herodias'un evliliğine karşı çıktığı için öldürüldüğü anlatılmaktadır. ${ }^{101}$ Haşmoni hanedanlığının son kız üyeleriyle evlenmenin Herod'un oğullarının tahta çıkışları için bir liyakat göstergesi gibi görüldüğü düşünülünce bu muhalefetin politik yansımaları böyle bir katlin sebebi olmalıdır. Vaftizci Yahya’nın politik bir mücadelenin ortasında yer alarak bu evliliğe karşı çıkması Haşmoni hanedanlığının son kadın üyesi Herodias’ın onu acımasızca öldürtmesine sebep olmuştur. Yahya’nın muhalefetine bu kadar sert bir şekilde tepki verilmesi Yahya’nın halk arasında önemli bir yeri olduğunu göstermektedir diyebiliriz. Bu olasılık babası Zekeriya’nın Başkohen olduğu rivayeti ile güç kazanmaktadır. ${ }^{102}$

Herod ve varislerinin elde etmeye çalıştığı soy ayrıcalığı anlayışını, bir soylu olmasına rağmen Vaftizci Yahya, ismiyle söylemiyle reddetmektedir. Yahya’nın isimlendirilmesi İncil ve Kurân'a konu olan bir hadisedir. İncil'de Zekeriya’nın, oğluna Yahya ismini vermesi ayrıntılı bir şekilde işlenmiştir. ${ }^{103}$ Yahya ismi, annesi Elişa’ya Tanrı tarafından bildirilmiştir.

98 Josephus, The Antiquities of the Jews, 17. 12

100 Josephus, The Antiquities of the Jews, 17. 89.

101 Markos 6:17-29; Matta 14:3-11.

102 Kanonik İncilerin dışında kalan Yakup İncili, Zekeriyảnın Başkohen olduğunu belirtmektedir (Yakup İncili 8:2). Sarıkçığlu, Diğer İnciller, s. 53-54. Apokrif İncillerde göze çarpan diğer bir husus Herod’un İsa gibi Yahya’yı da çocukken öldürtmeye çalışmasıdır (Yakup İncili 23:1-2; Serapion’a Göre Yahya’nın Hayatından Kısımlar; Sarıkçığlu, Diğer İnciller, s. 81). Her ne kadar Herod'un iki yaşından küçük her çocuğu öldürdüğü söylense de (Masumlar Katli: Matta 2:17) kanaatimizce bu takibatı Herod’un sadece tahtı için tehlikeli gördüğü Haşmonilere ve Başkohen ailelerine uygulanmış olması daha makul görünmektedir.

103 Elizabet'in (Elisa) bir erkek bebeğini doğurmasının sekizinci gününde, Yahudi geleneğine göre sünnet edilip adı verilecekti. Yahudi geleneğine göre ilk erkek çocuğuna akrabalarından birinin adı (özellikle babasının adı) konulurdu. Fakat Elisa Tanrı’nın iradesine uyarak Yahya adını seçmek istediğini söyledi. Akrabaları Zekeriya’nın fikrini sorduğunda konuşamayan Zekeriya ince tahtaya Yahya diye yazmıştı. O an Zekeriya’nın ağzı açıldı ve Yahya yüce Tanrı'nın peygamberidir dedikten sonra bayıldı (Luka 1:59). Kurân, Yahya isminin Allah tarafından konulduğu konusunda İncil ile hem fikirdir. 
Akrabaları bu isme itiraz etmiş, Zekeriya, bir tahtaya Yahya ismini yazmış daha sonra bu ismi söyleyerek bayılmıştır. Kur'ân'da Meryem sûresinin ilk âyetleri Zekeriya’nın oğlu Yahyảnın, babasına ve Âl-i Ya'kub’a varis olması ${ }^{104}$ ve onun isimlendirilmesi konusuna ayrılmıştır. 7. âyeti Yahya isminin daha önce kullanılmadı̆̆ 1 şeklinde yorumlanmış ve bu yorum Yahudi-Hıristiyan-Müslüman polemiğine yeni bir madde katmıştır. Abraham Geiger, Yahya isminin Yuhanna’nın bir okunuşu olduğunu dolayısıyla Kur'ân’ın yine bir bilgi hatası yaptığını söylemektedir. ${ }^{105} \mathrm{Biz}$ ise bu bağlamda Yahya ve Yuhanna isimlerinin birbirinin aynısı olmadığını düşünmekle beraber başka bir noktaya dikkat çekmek istiyoruz. ${ }^{106}$ Yahya’nın isimlendirilmesi niçin bu kadar önemlidir? Bu isimlendirmenin altında devrin dinamiklerine bir meydan okuma mı vardır?

$\mathrm{Bu}$ sorulara cevap vermeden önce bir parantez açarak Yahya ismi iddia edildiği gibi Yuhanna ile aynı isimse isimlendirme konusunda başka bir eleştirinin daha olması gerekmektedir. Şöyle ki Yuhanna, Haşmoni ailesinin kullanmış olduğu bir isimdir. Mattatiyus'un oğullarından birinin ismi Yuhanna'dır. Bu isimle meşhur olan kişi ise hiç şüphesiz Yuhanna Hirkanus ve II. Hirkanus'tur. ${ }^{107}$ Kanaatimizce II. Alexander'ın kayıtlara geçmeyen İbranice

104 Kurân Hz. Yakup’un soyundan gelenler için “Beni İsrail” ve "Âl-i Ya‘kub” tabirlerini kullanır. Bu iki tabir arasında umumi ve hususi anlam ayrımı yapılmaktadır: "Hz. Ya'kub’un lakabı İsrâil olduğundan onun soyundan gelenlere Benî İsrâil de denilmektedir. Âl-i Ya'kub ve Benî İsrâil tabirleri muhteva farklılı̆̆ına rağmen aynı kavmin insanlarını ifade etmektedir. Muhteva bakımından Benî İsrâil umumi, Âl-i Ya’kub ise hususidir. Benî İsrâil ile, Hz. Yakup’un soyundan, dininden olan veya olmayan milleti, Âl-i Ya'kub ile de onun aile fertleri, oğulları, torunları ve doğrudan onun soyundan, dininden olan ümmeti kastedilmektedir. Çünkü Kurân’da gerek Âl-i Ya‘kub tabirinin geçtiği âyetlerde, gerekse o sülâleden bahseden diğer âyetlerde onların Allah’ın emrine uydukları, ibadet ettikleri, atalarının dinini benimsedikleri belirtilmekte ve onlar için bir kınama söz konusu edilmemektedir. Benî İsrâil tabirinin geçtiği âyetlerde ise onlara verilen nimetler anlatılmakta, Allah'tan başkasına kulluk etmeyeceklerine, anaya babaya, akrabaya, yetimlere, yoksullara iyilikte bulunacaklarına, insanlara güzel söz söyleyeceklerine, namaz kılıp zekât vereceklerine, birbirinin kanını dökmeyeceklerine, birbirini yurtlarından çıkarmayacaklarına dair söz verdikleri hatırlatılmakta ve genellikle verdikleri sözden döndükleri belirtilmekte, bundan dolayı da kınanmaktadırlar. Böylece, bir kısmı hariç, Benî İsrâil tabiriyle doğru yoldan sapmış olan Yâkuboğulları’nın kastedildiği ortaya çıkmaktadır” (Küçük, "Âl-i Ya‘kub”, DİA, II, 310). Âl-i Ya‘kub ve Benî İsrail arasında yapılan umumi ve hususi ayrım, Zekeriya’nın niçin Âl-i Ya'kub ifadesini kullandığını açıklar. Ancak Zekeriya niçin Âl-i İbrahim değil de Âl-i Ya`kub ifadesini kullanmıştır? Kanaatimizce Zekeriya’nın duasında Âl-i Ya‘kub tabirini seçmesinde Edomlulara ve İsmaili Araplara bir gönderme bulunmaktadır. Zira Edomlular İshak’n oğlu Esav soyundan, İsmaililer, İbrahim’in İsmail soyundan gelmektedir. Dolayısıyla Zekeriya duasında Âl-i İbrahim değil de Âl-i Ya‘kub diyerek en azından bu iki toplumdan farklı olan, kendi soyuna varis istemektedir. Zekeriya’nın bu şekilde dua ederek soyu önemsemesi İslâm’n kan birliğinden ziyade din birliğine önem verdiği anlayışına da ters düşmeyecektir. Zira İslâmi anlayışta üstünlüğe ve seçilmişliği esas olan din birliği olmakla beraber onlar arasında kan birliği olmayacağ anlamına gelmemektedir. Öyle ki Kurân Âl-i İbrahim ve Âl-i İmrân’nın âlemlere üstün kılındığını bildirir (Âl-i İmrân 3/33). Ayrica İbrahim'den uzanan soy silsilesine de zaman zaman yer verir (el-Bakara 2/133, 136, 140; Âl-i İmrân 3/84: en-Nisa 4/163). Neticede Zekeriya, Yusuf kıssasında Yakup’un Yusuf'a söylediğine benzer bir duada bulunur: "Anlaşılan böylece rabbin seni seçecek, sana rüyada görülenlerin yorumunu öğretecek ve daha önce ataların İbrahim ve İshak’a nimetini tamamladığı gibi sana ve Yakup soyuna da nimetini tamamlayacaktır. Kuşkusuz rabbin çok iyi bilendir, hikmet sahibidir" (Yusuf 12/6).

105 Geiger, Judaism and Islam, s. 19.

106 bk. Islamic Awarness, "And No One Had The Name Yahya (= John?) Before".

107 II. Hirkanus'un İbranice isminin Yuhanna olduğu söylenmekle beraber Yonatan ismi de kayıtlar arasındadır. Uzun bir süre hatalı olarak Yuhanna ve Yonatan ismi aynı isimler olarak kabul edilmişlerdir. Ancak bu isimlerden ilki "Yahve bağıșlayıcıdır" anlamında İbranice, Yochanan'dan; ikincisi ise "Yahve verdi” anlamında İbranice Yehonatan'dan gelir. 
ismi de Yuhanna'dır. ${ }^{108}$ Bilindiği gibi Yahudi geleneğinde isim koyma oldukça önemli bir konu olup belirli kuralları ve adetleri barındırmaktadır. Bu adet, isim koymada öncellik hakkı, isim seçiminde harf sayısına dikkat etmeye kadar detaylarıyla ele alınmaktadır. Ayrıca verilen isim ile çocuk arasında bir irtibat kurulmaktadır. ${ }^{109}$ Ancak bizim dikkatimizi çeken husus Yahya’nın Haşmoni hanedanlığının meşhur isimlerinden birini almasına yönelik hiçbir eleştirinin bulunmamasıdır. Ayrıca Yahya’ya, itibar kaybeden Haşmonilerin meşhur isimlerinden birinin verilmesi isim âdetine ters düşmektedir. Yahya’nın isimlendirilmesi konusunda bu tarz bir eleştirinin bulunmaması Yahya ile Yuhanna isminin birbirinden farklı isimler olduğunu akla getirmektedir.

Esas sorumuza dönecek olursak soylu bir aileden gelen -belki de bir Başkohen olan- Zekeriya’nın oğluna Yahya ismi verilmesinin her iki kutsal kitaba da konu olmasının sebebi kanaatimizce devrin isim adetlerine dolayısıyla soyun üstünlüğüne sert bir muhalefet içermesidir. Böylelikle Kurân'da belirtildiği üzere Yahya isminin daha önce duyulmamış olması ayrıntısının esas vurgulamak istediği nokta, Zekeriya’nın dönemin adetlerinin dışına çıkmış olmasıdır. Soylu bir aileden gelen Zekeriya, Allah’ın emriyle oğluna Yahya ismini vererek bu âdeti ayaklar altına almakla soyun üstünlüğü düşüncesine başkaldırmış olmaktadır. İncillerde ve Kur'ân'da Zekeriya’nın oğlunun isimlendirilmesini bu kadar önemli kılan husus -hatta Zekeriya'nın bayılmasına sebep olan durum- kanaatimizce Haşmoni Krallığı döneminde aşırı önem kazanan soy üstünlüğüne bir reddiye olmasıdır. Vaftizci Yahya ve ötesinde İsa’nın annesi Meryem ${ }^{110}$ soylu bir aileden gelmektedirler. Yahya’nın isminin, Mabed'deki bir ibadet esnasında Allah tarafından bildirilmesi, Meryem'in Mabed'e adanması ve Kohenlerin onun bakımı için kura çekmeleri alışılagelmiş olaylar olarak gözükmemektedir. Bununla birlikte Yahya yaşantısıyla soyun sağladığı ayrıcalıkları reddeden bir kişi olarak karşımıza çıkmaktadır. Babasının soyu ve konumundan anlaşılacağı üzere Kohen olan Yahya, Mabed hizmetini üstlenmek yerine mensup bulunduğu sinıfı terk ederek züht hayatı sürmek için Ürdün nehrinin çevrelediği çöle çekilir ve bu nehirde insanları vaftiz eder. Vaftiz, Yahudilikte önceden var olan bir uygulama olmasına rağmen ${ }^{111}$ Yahya’nın vaftizinin

108 Babil sonrası çocuğa amca ve dedenin ismini verme âdetini en iyi uygulayan şüphesiz Haşmonilerdir. Bu adet Oniaslar'da da görülmektedir. Makkabi harekâtının kurucusu olan Matatiyas'dan başlamak üzere, son üye sanılan III. Aristobulus’a kadar amca ve dede isminin tekrarı vardır. Öyle ki bu isimlendirme âdetini Büyük Herod devam ettirmiş, I. Meryem'den olan iki oğlundan ilki olan Alexander’a anne dedesinin ismini, ikinci oğlu IV. Aristobulus' a da dayısının ismini vermiştir.

109 Wilhelm, "What's in a Name?".

110 Kanaatimizce Meryem ve İsa’nın soyunu Kurân’ın gizemli şahsı İmrân’ın kimliği belirleyecektir. Bu konuda detaylı ve çok yönlü bir araştırma yapılması gerekmektedir. Bu araştırmada İnciller'in İsa için sunduğu Davudi şecerenin kısıtlamasından kurtulmak ilk adım olacaktır. İkinci olarak İmrân’n bir soy ismi olmasından ziyade Meryem’in gerçek babasının ismi olduğunu kabul ederek bu gizemli şahsın izlerini Büyük Herod döneminde aramak daha isabetli olacağı kanısındayız. İmrân’ın kimliği konusundaki yorumlar için bk. Harman, "İmrân", DİA, XXII, 232.

111 Elişảnın İlyas’ın eline su döktüğü ve Elişảnın Neheman’a temizlenmesi için Ürdün nehrinde yedi kez yedi kez yıkanması gerektiğini söylediği II. Krallar 3:11 ve 5:10’ da yer alır. Yahudiliğin erken dönemlerinde vaftiz Hasidiyanlar ve Essenîler tarafından uygulanmaktadır (Kohler-Krauss, "Baptism", Jewish Encyclopedia, II, 499). İkinci mabed döneminde Helenistik gizem dinlerinin etkisiyle suya girme âyinleri çoğalmış ve cemaate katılımın şartı olarak inisiyasyon vaftizi çeşitli yahudi grupları tarafından (Essenîler ve Kumran cemaati) uygulanmıştır (Gürkan, "Vaftiz", DİA, XLII, 425). 
sembolik bir anlamı vardır. Buna göre vaftiz olan kişi her türlü kirden arınmakta ve Tanrı’nın affına mazhar olmaktadır. Vaftizin bu anlamı Mabed'deki aristokrat yapılanmaya bir meydan okumadır. ${ }^{112}$ Aynı zamanda Yahya, İbrahim Peygamberin soyundan gelmenin kişiyi kurtuluşa ulaştırmadığını vurgulayarak bu meydan okumayı daha da derinleştirmektedir. Öyle ki Yahya vaftiz olmak için kendisine gelenlere şu şekilde seslenmektedir:

Ne var ki, Ferîsîlerle Sadûkîlerden birçok kişinin vaftiz olmak için kendisine geldiğini gören Yahya onlara şöyle seslendi: «Ey engerekler soyu! Gelecek olan gazaptan kaçmanız için sizi kim uyardı? ${ }^{8}$ Bundan böyle tövbeye yaraşır meyveler verin. ${ }^{9}$ Kendi kendinize, 'Biz İbrahim'in soyundanız' diye düşünmeyin. Ben size şunu söyleyeyim: Tanrı, İbrahim’e şu taşlardan çocuk yaratacak güçtedir. ${ }^{113}$

Yahya, "Seçilmiş Din” ve "Seçilmiş Millet” arasındaki tercihini ilkinden yana kullanmış, seçkin millet anlayışına karşı çıkmış, Tanrı katında hiçbir kişinin veya milletin doğrudan kurtuluşu hak etmediğini, kurtuluşun ancak Tanrı'nın iradesine uygun bir yaşam sürmekle elde edilebileceğini söylemiştir. ${ }^{114}$

Haşmoni Krallı̆̆ı’nın son günlerinde yaşamış olan iki önemli şahsiyet (Herod-Yahya) soy üstünlüğü konusunda tamamen farklı yollar izlemişlerdir. Büyük Herod soy asilliğini evlilik yaparak kazanmaya çalışırken; Yahya soy üstünlügünnde reddi miras yaparak kurtuluşu Tanrı'nın emirlerine uymaya bağlamıştır.

\section{Sonuç}

Makkabilerin bölgenin siyasi belirsizliğinden yararlanarak kurmuş olduğu Haşmoni Krallığı, soyları sebep gösterilerek siyasi ve dini erki kullanmada bir takım sınırlamalara maruz bırakılmıştır. Haşmoniler dini otoritelerini Sanhedrin ile paylaşmak durumunda kalmış; Davut soyundan olmadıkları öne sürülerek krallıklarının meşruiyetinin halk tarafından tanınması ve desteklenmesi engellenmiştir. Helenleşen Haşmoni Hanedanlığına karşı dini otoritelerin soy iddiaları üzerinden gerçekleştirdiği dolaylı muhalefet krallı̆̆ın tarih sahnesinde ancak yüz yıl kalmasıyla sonuçlanmıştır.

\footnotetext{
112 Aydin, "Yahya", DİA, XLIII, 432.

113 Matta 3:9.

114 Kurân’n “Ey Yahya! Kitaba sımsıkı sarıl!” emrinin de buna işaret ettiğini düşünmekteyiz (Meryem 19/12). Yahyảnın kurtuluşu dinin emir ve yasaklarına sımsıkı sarılmaya bağlı olduğunu düşünmesi, onu devrin hâkim sınıfı Sadûkîlerden uzaklaştırmaktadır. Bu açıdan Yahya peygamber Ferîsîlere daha yaklaşmaktadır. Zira Ferîsîler İsrailoğulları’nın üstünlüğüne inanmakla beraber onlara göre zorunlu husus 'dinin muhafazası'dır (Kutluay, İslâm ve Yahudi Mezhepleri, s. 223). Bunun yanında Yahya peygamberi, Essenîlere yaklaştıran husus ise onun kendini tarif edenlerken kullandığı tabirdir. Essenîler kendilerini "Çölde yol hazırlayanlar" diye tarif ederken Yahya peygamber de kendi vazifesini tarif ederken aynı tabiri kendisi için kullanmıştır (Yuhanna 1:23) (Kutluay, İslâm ve Yahudi Mezhepleri, s. 247).
} 
Ayrıca Haşmonilerin, merkezi ve yayılmacı siyasi anlayışının bir sonucu olarak Edomlular gibi toplulukları Yahudileştirme politikası dönemin Yahudi gruplarının arasındaki fikri ayrılıkları derinleştirmiştir. Soya dayalı sınıf farklarının oluştuğu bir ortamda bir soylu olmasına rağmen Vaftizci Yahya dönemin soy anlayışına karşı çıkmış olsa da bu muhalefet sınırlı kalmıştır. Bu dönemde Yahudilik "Seçilmiş Millet” anlayışını etnik unsurlardan arındırsa da, tam anlamıyla evrensel bir din olmaya geçiş yapamamıştır. Yahudiliğin içinden çıkan Hristiyanlığın yayılmacı özelliği bu dönemden esinlenmekle beraber İnciller’in İsảnın Davut soyundan geldiğini ispatlamaya çalışan şecerelerle başlaması soyun sağlamış olduğu üstünlükten hala kopulamadığının en açık göstergesi olarak kabul edilebilir.

Şekil 1. Haşmonayim Hanedanlığı

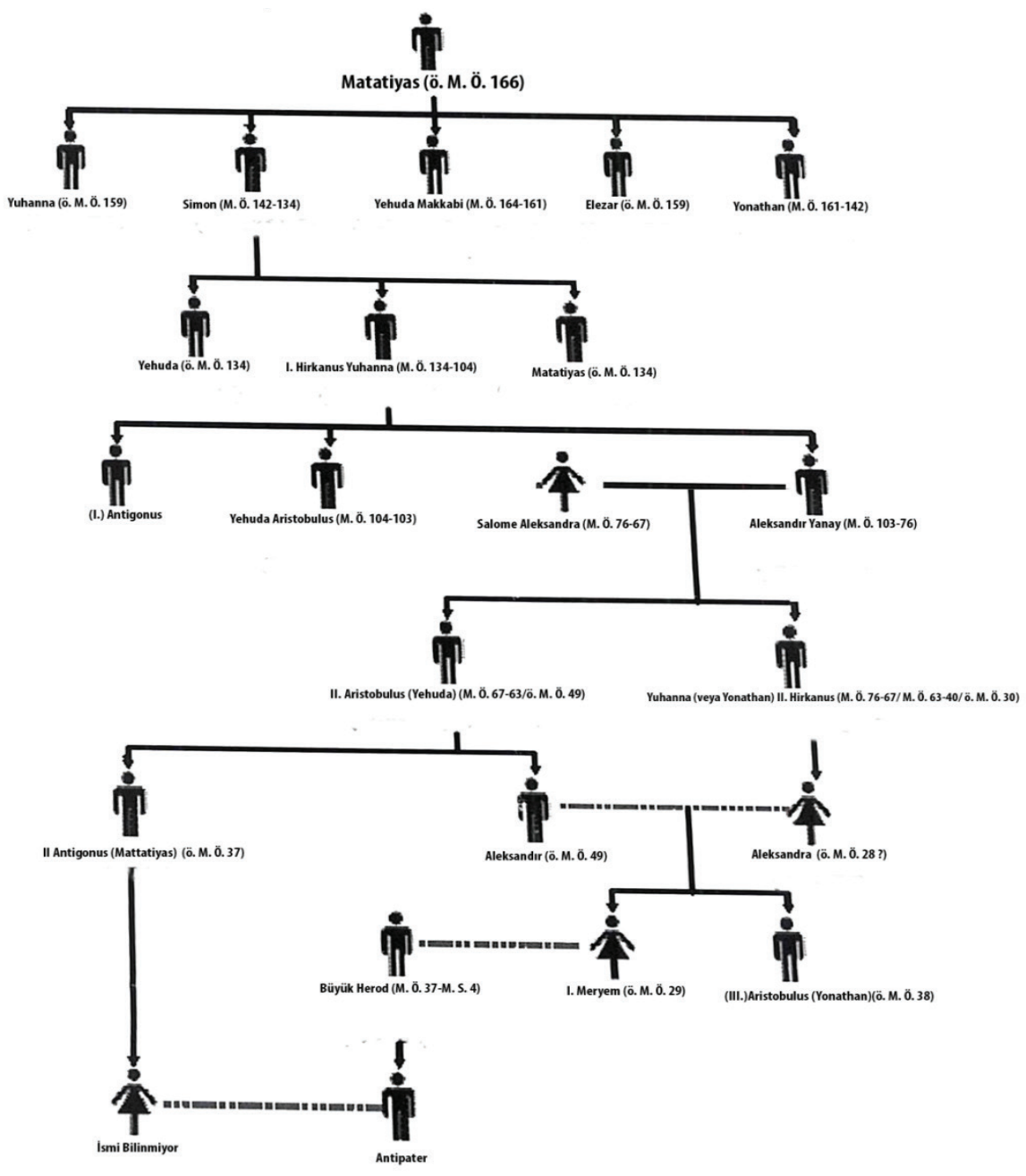




\section{Kaynaklar}

Arslantaş, Nuh, "Re’sülcâlût", DİA, XXXV, 5-6.

Atkinson, Kenneth, Queen Salome Jerusalem's Warrior Monarch of the First Century B. C. E, Jefferson, North Calorina : McFarland \& Co, 2012.

The Babylonian Talmud (ed. Rabbi Epstein), London: The Soncino Press, 1978.

Baumgarten, A. I., "The Name of the Pharisees", Journal of Biblical Literature, 1983, CII, sy. 3, s. 411-428.

ha-Bavli, Natan, Seder Olam Zuta: Dünyanın Kısa Tarihi (trc. Nuh Aslantaş), Ankara: Türk Tarih Kurumu, 2014.

Bickerman, Elias, From Ezra to the Last of the Maccabees, New York: Shocken Books, 1949.

Dąbrowa, Edward, The Hasmoneans and Their State, Kraków: Wydawnictwo Uniwersytetu Jagiellońskiego Wydanie, 2010.

Encyclopedia Judaica, “Zugot”, XXI, 680.

Eyal, Regev, The Hasmoneans Ideology, Archaeology, Identity, Göttingen: Vandenhoeck\&Ruprecht, 2013.

Finkelstein, Louis, "The Pharisees: Their Origin and Their Philosophy", The Harvard Theological Review, 1929, XII, sy. 3, s. 185-261.

Geiger, Abraham, Judaism and Islam (trc. F. M. Young), Vepery: M.D.C.S.P.C.K. Press, 1898.

Ginzberg, Louis, “Alexander Jannæus (Jonathan)”, Jewish Encyclopedia, I, 352-354.

Goldstein, Jonathan A., I Maccabees, New York: Doubleday, 1976.

Gürkan, Salime Leyla, Yahudilik, İstanbul: İSAM, 2012.

------, "Vaftiz", DIA, XLII, 424-426

Harman, Ömer Faruk, "İmrân”, DİA, XXII, 232.

Hendin, David, "Numismatic Expressions of Hasmonean Sovereignty", Israel Numismatic Journal, 20072008, sy. 16. s. 76-91.

Ilan, Tal, "The Greek Names of the Hasmoneans", The Jewish Quartely Review, 1987, LXXVIII, sy. 1-2, s. $1-20$.

------, "Queen Salamzion Alexandra and Judas Aristobulus I’s Widow: Did Jannaeus Alexander Contract a Levirate Marriage?", Journal for the Study of Judaism, 1993, sy. 24, s. 181-90.

Islamic Awareness, "And No One Had The Name Yahya (= John?) Before: A Linguistic \& Exegetical Enquiry Into Qur'an 19:7" http://www.islamic-awareness.org/Quran/Contrad/External/yahya.html (erişim tarihi: 29.05.2017).

Joseph-Kohler: Jacobs, Joseph-Kaufmann Kohler, “Nasi”, Jewish Encyclopedia, 9, s. 171-172

Josephus, Flavius, The Antiquties of the Jews (trc. William Whiston), http://www. perseus. tufts. edu/hopper/ text?doc=Perseus:text:1999. 01. 0146 (erişim tarihi: 29.05.2017).

-----, The Wars of the Jews (trc. William Whiston), http://www. perseus. tufts. edu/hopper/ text?doc=Perseus:text:1999. 01. 0148 (erişim tarihi: 29.05.2017).

Klawans, Jonathan, "Sadducees, Zadokites and the Wisdom of Ben Sira”, David B. Capes vd. , Israel's God Rebecca's Children, Baylor University Press, 2008, s. 261-276.

Kohler-Krauss: Kohler, Kaufmann-Samuel Krauss , “Baptism”, Jewish Encyclopedia, II, 499-500.

Kurt, Ali Osman, Babil Sürgünü Sonrası Ezra Önderliğinde Yahudiliğin Yeniden Yapılandırılması (doktora tezi, 2006), Ankara Üniversitesi SBE.

Kutluay, Yaşar, İslâm ve Yahudi Mezhepleri, İstanbul: Anka Yayınları, 2001.

Kutsal Kitap, http://www. kutsal-kitap. net (erişim tarihi: 29.05.2017).

Küçük, Abdurrahman, “Al-i Ya'kub”, DİA, II, 309-310. 
Lamm, Maurice, “Kohen Marriages", chabad. org http://www. chabad. org/library/article_cdo/aid/468267/ jewish/Kohen-Marriages. htm (erişim tarihi: 29.05.2017).

Main, Emmanuelle, “Yannai (Jannaeus) Alexander”, Encyclopedia Judaica, XXI, 282-283.

Mansoor, Menahem, "Hassideans", Encyclopedia Judaica, VIII, 455.

Mantel, Hugo, “Sanhedrin”, Encyclopedia Judaica, XVIII, 21-23

Milwitzky, William, Alexandra, Jewish Encyclopedia, I, 358-359.

Rappaport, Uriel, “Nicanor”, Encyclopedia Judaica, XV, 247.

------, "Maccabean Revolt", New Interpreter's Dictionary of the Bible, IV, 434.

-----, "Menelaos", Encyclopedia Judaica, XIV, 46.

Rosenberg, Stephen G. , “Tobiads”, Encyclopedia Judaica, XX, 9-11.

------ "Temple of Onians", Encyclopedia Judaica, XV, 432-433.

Sarıkçıŏlu, Ekrem, Diğer İnciller (Apokrif İnciller), Isparta: Fakülte Kitapevi, 2005.

Schofield-VanderKam: Schofield, Alison-VanderKam, James C., "Were the Hasmoneans Zadokites?", Journal of Biblical Literature, 2005, CXXIV, sy. 1, s. 73-87.

Schürer, Emil, A History of Jewish People in the time of Jesus Christ, 3 (trc. Sophia Taylor-Rev. Peter Christe), Edinburgh: T\&T Clark, 1886.

Singer-Lauterbach: Singer, Isidore- Lauterbach, Jacob Zallel, "Joshua B. Perahyah", Jewish Encyclopedia, VII, 295.

Tcherikover, Victor, Hellenistic Civilization and the Jews, New York: Atheneum, 1975.

VanderKam, James C. , From Joshua to Caiaphas, Minneapolis: Fortress Press, 2004.

Wilhelm, Zushe, "What's in a Name?", chabad. org http://www. chabad. org/library/article_cdo/aid/273280/ jewish/Whats-in-a-Name. htm (erişim tarihi: 29.05.2017).

Zeitlin, Solomon, "Queen Salome and King Jannaeus Alexander: A Chapter in the History of the Second Jewish Commonwealth", The Jewish Quarterly Review, 1960, LI, sy. 1, s. 1-33.

-----, “The Origin of the Pharisees Reaffirmed”, The Jewish Quarterly Review, 1969, LIX, sy. 4, s. 255-267.

-----, “The Pharisees: A Historical Study”, The Jewish Quarterly Review, 1961, LII, sy. 2, s. 97-129.

-----, “The Titles High Priest and the Nasi of the Sanhedrin”, The Jewish Quarterly Review, 1957, XLVIII, sy. 1, s. 1-5. 